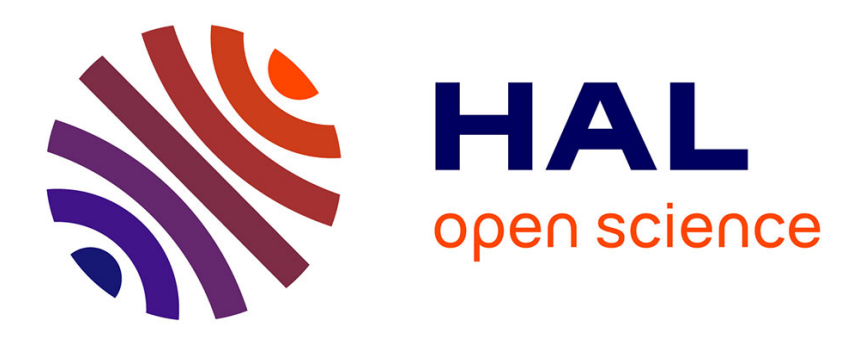

\title{
Dipyrrin based metal complexes: reactivity and catalysis Stephane Baudron
}

\section{To cite this version:}

Stephane Baudron. Dipyrrin based metal complexes: reactivity and catalysis. Dalton Transactions, 2020, 49 (19), pp.6161-6175. 10.1039/D0DT00884B . hal-02911850

\section{HAL Id: hal-02911850 \\ https://hal.science/hal-02911850}

Submitted on 24 Aug 2020

HAL is a multi-disciplinary open access archive for the deposit and dissemination of scientific research documents, whether they are published or not. The documents may come from teaching and research institutions in France or abroad, or from public or private research centers.
L'archive ouverte pluridisciplinaire HAL, est destinée au dépôt et à la diffusion de documents scientifiques de niveau recherche, publiés ou non, émanant des établissements d'enseignement et de recherche français ou étrangers, des laboratoires publics ou privés. 


\title{
Dipyrrin based metal complexes: reactivity and catalysis
}

\author{
Stéphane A. Baudron* \\ Université de Strasbourg, CNRS, CMC UMR 7140, 4 rue Blaise Pascal, F-67000, Strasbourg, France. \\ Fax: 33 368856711; Tel: 33 368851323; E-mail: sbaudron@unistra.fr,
}

Sometimes coined half-porphyrins, the bis-pyrrolic dipyrrin ligands endow their metal complexes with unique properties such as the potential to functionalize the heterocyclic backbone or the meso position as well as the ability to catalyze interesting chemical transformations. Thus, strategies towards the derivatization of or at the meso group and the use of dipyrrin metal complexes for the formation of a broad range of polypyrrolic derivatives such as 2,2'-bis-dipyrrins, nor-/hetero-corroles and porphynoids have been elaborated. Furthermore, the chelating ability of dipyrrins and the possibility to modify the steric and electronic characteristics by functionalization can be exploited for the development of numerous complexes featuring appealing properties. Hence, $\mathrm{C}-\mathrm{H}$ activation/amination, polymerization or oxidation reactions can be catalyzed by dipyrrin metal complexes and classical reagents such as Grignard species, Rh-based or Suzuki-Miyaura catalysts have been revisited by incorporation of dipyrrins in the coordination sphere of the metal cations. This contribution aims at reviewing and illustrating all these aspects, highlighting the potential of these complexes for the design and synthesis of valuable organic compounds and metallo-organic architectures.

\section{Introduction}

The bis-pyrrolic dipyrromethene derivatives, also coined dipyrrins (dpm) (Fig. 1), ${ }^{1}$ known for almost a century, ${ }^{2}$ have received a revived interest since the 1990s. BODIPYs, their boron difluoride adducts, (Fig. 1), have been particularly studied as they represent an important class of dyes with applications in sensing, ${ }^{3-4}$ therapy ${ }^{5-6}$ or photovoltaics, ${ }^{7}$ among others. The metal complex analogues have, for their part, been investigated for their optical and photophysical properties ${ }^{8-9}$ as well as for the preparation of coordination polymers, ${ }^{10}$ supramolecular assemblies ${ }^{11}$ and for material applications. ${ }^{12}$ Owing to their conjugated bis-pyrrolic nature, dipyrrins are often seen as "half-porphyrins". This analogy is noteworthy, since it suggests that dipyrrin metal complexes may also feature interesting reactivity and catalytic activity. Indeed, porphyrins and related tetrapyrrolic macrocycles such as corroles, endowed with unique optical and electrochemical properties, are involved in a variety of biological processes and are capable of catalysing a diversity of reactions. ${ }^{13-16}$ Furthermore, these derivatives can be readily functionalized at the pyrrolic and peripheral positions. ${ }^{17-18}$ Over the past decade, the potential of dipyrrin metal complexes to act as reactive templates for the formation of more elaborate architectures or to catalytically produce chemicals of high added value, thus paralleling porphyrins and their cousins, has been explored. This contribution aims at giving an overview of these recent efforts. The functionalization or modification of the dipyrrin backbone and/or of its peripheral moieties will be first described, highlighting the reactivity of the scaffold and its ability to produce other polypyrrolic systems and assemblies. Catalysis based on dipyrrin metal complexes for a wide array of reactions will then be presented, emphasizing the potential of these derivatives in synthetic chemistry.

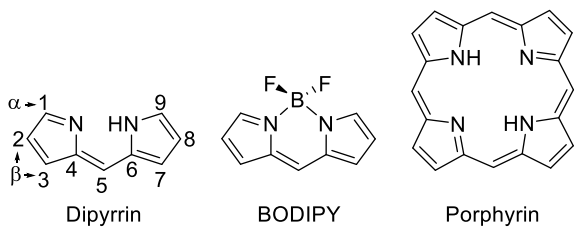

Fig. 1. Representation of a dipyrrin, a BODIPY and a porphyrin. No functional groups have been presented at the pyrrolic and meso positions for clarity. 


\section{Functionalization of dipyrrin metal complexes}

While functionalization of the boron $\mathrm{dpm}$ core has been recognized as an efficient approach for the preparation of a diversity of BODIPYs, ${ }^{19}$ this strategy has been much less explored for the postsynthetic preparation of derivatized dpm metal complexes.

\subsection{Reactivity at the meso group}

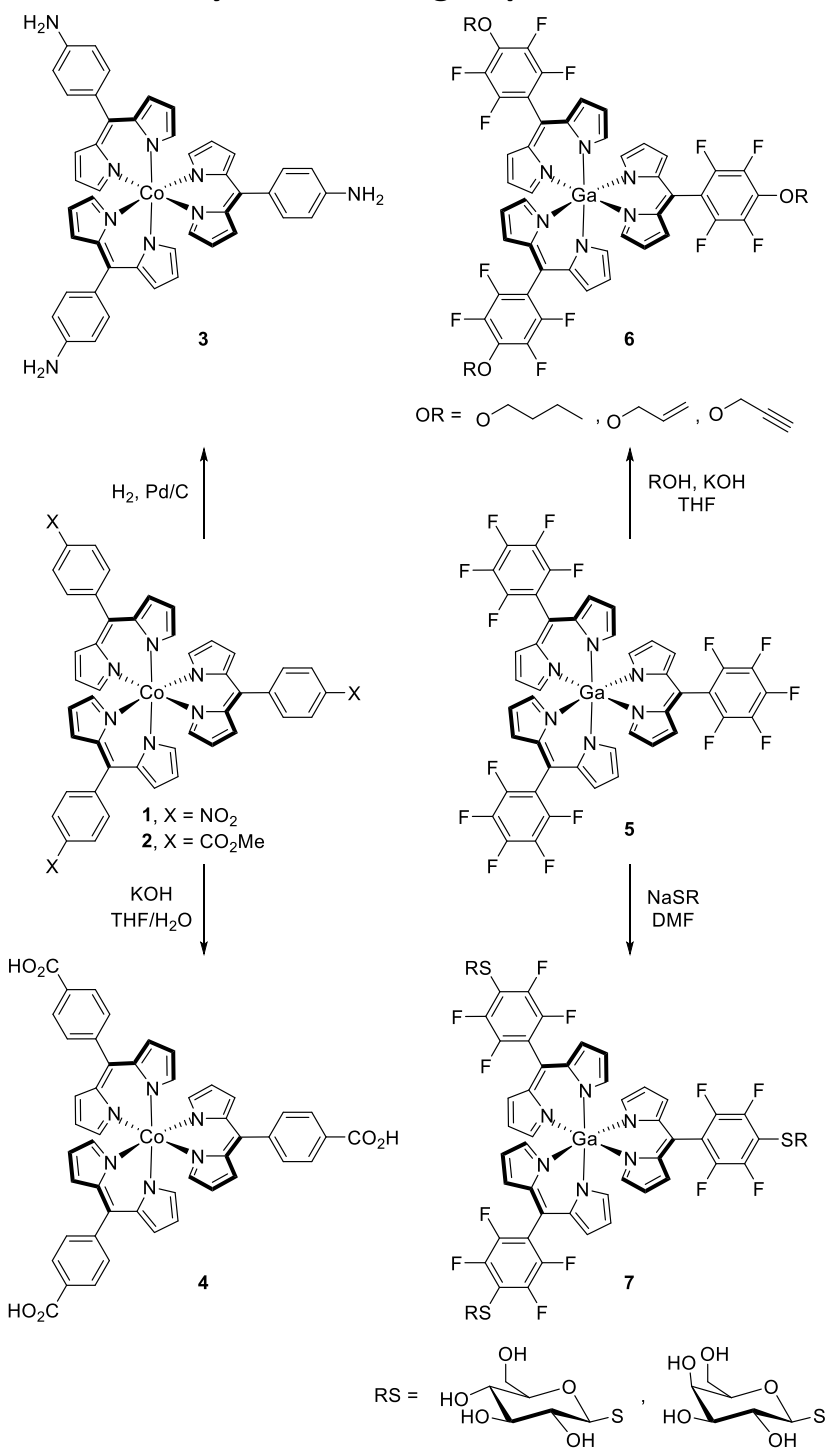

Fig. 2 Post-synthetic functionalization of trivalent $M(\mathrm{dpm})_{3}$ complexes as described by Dolphin (left) ${ }^{20}$ and Wiehe (right). ${ }^{25}$ For all compounds, only one enantiomer of the tris-chelate complex is presented for clarity.

In a seminal article, Dolphin and coworkers took advantage of the inertness of $\mathrm{Co}(\mathrm{dpm})_{3}$ complexes for their post-synthetic functionalization. ${ }^{20}$ Thus, the nitro derivative 1 was converted to the amino analogue $\mathbf{3}$ by hydrogenation ( $78 \%$ yield), while the ester-appended complex $\mathbf{2}$ was converted to the corresponding carboxylic acid 4 by saponification (90\% yield) (Fig. 2 right). The saponification can be taken advantage of to introduce an additional coordinating and reactive group that can be used for the formation of MOFs ${ }^{21}$ and heterometallic assemblies, ${ }^{22}$ employed for further functionalization such as introduction of hydrogen bonding units ${ }^{23-24}$ or to separate $\Delta$ and $\Lambda$ enantiomers upon reaction with cinchonidine. ${ }^{21,23-24}$

More recently, following an analogous approach, $\mathrm{Ga}$ (III), In(III) and Fe(III) complexes based on a pentafluorophenyl appended dpm have been derivatized to allow the introduction of alcohol or thio- 
carbohydrates. These functionalizations proceeded with moderate to good yields ( 21 to $88 \%$ ) and the corresponding conversion of the Ga(III) complex $\mathbf{5}$ to $\mathbf{6}$ and $\mathbf{7}$ respectively is illustrated in Fig. 2. This post-synthetic strategy is valuable as it allowed grafting of thiosugars that would be otherwise prone to oxidation under the conditions classically employed in dpm chemistry (synthesis of dipyrromethane, oxidation to $\mathrm{dpm}$ followed by complexation). The $\mathrm{Ga}$ (III) complexes of type $\mathbf{7}$ were shown to feature phototoxic activity towards different cell lines (human epidermoid carcinoma A253, human epithelial carcinoma A431, human oral adenosquamous carcinoma CAL 27 and colorectal adenocarcinoma HT29) and the ability to photodynamically inactivate $S$. aureus bacteria. ${ }^{25}$ It is worth noting that the Fe(III) analogues were shown to not have any activity owing to their different photophysical properties. A similar functionalization strategy was also employed by the same authors for the derivatization of heteroleptic Ru complexes, for which introduction of alcohol, thiosugar and also amino groups could be performed.

Lindsey and coworkers have employed divalent metal complexes 8 and 9 ( $\mathrm{M}=\mathrm{Pd}(\mathrm{II}), \mathrm{Zn}(\mathrm{II})$ ) based on a para-iodophenyl dpm to build larger architectures using C-C coupling reactions (Fig. 3). Hence, Suzuki-Miyaura coupling of Pd complex $\mathbf{8}$ with porphyrin $\mathbf{1 0}$ led to the formation of triad $\mathbf{1 1}$ in $50 \%$ yield. ${ }^{26}$ This heterometallic system was subsequently converted to an all $\mathrm{Zn}$ (II) compound showing an efficient energy transfer from the $\mathrm{dpm}$ unit to the peripheral macrocycles upon photoexcitation. Similarly, Sonogashira coupling of Zn complex $\mathbf{9}$ with dipyrromethane $\mathbf{1 2}$ led to complex $\mathbf{1 3}$ in $84 \%$ featuring both the reduced and oxidized forms of the bis-pyrrolic backbone. ${ }^{27}$

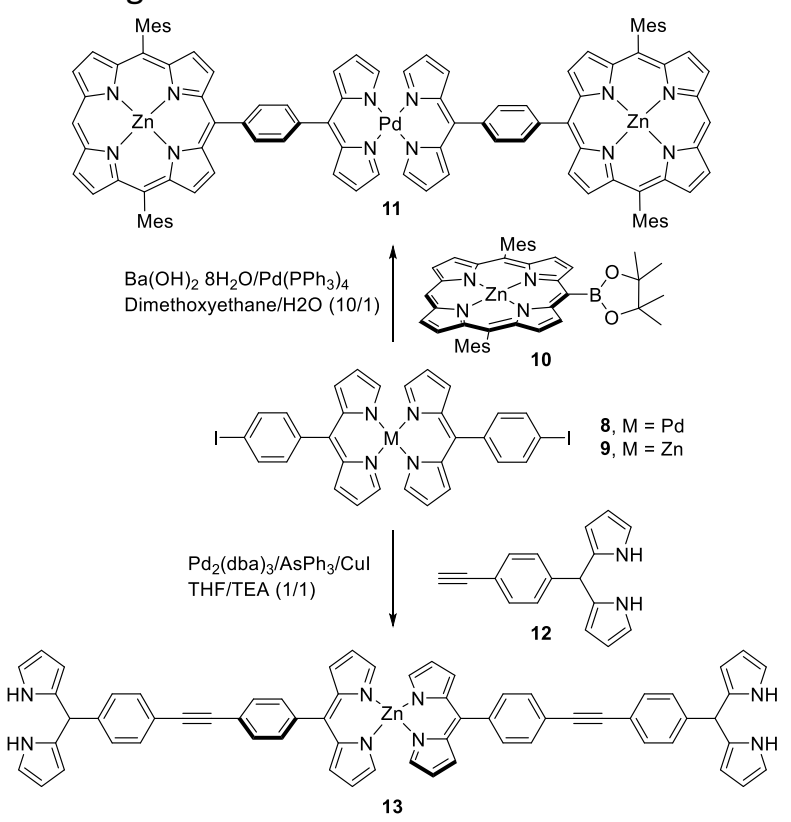

Fig. 3 Pallado-catalyzed couplings on divalent metal complexes based on a para-iodophenyl dpm, as described by Lindsey and coworkers. ${ }^{26-27}$ Mes $=$ mesityl.

While the previous examples relied on the presence of an aryl group at the meso position, the group of Telfer has described another approach for direct functionalization at this site. ${ }^{28}$ Inspired by a procedure developed for BODIPYs, ${ }^{29}$ they have prepared Re(I) complex $\mathbf{1 4}$ bearing a thiomethyl group at the meso position. The latter is prone to undergo nucleophilic substitution allowing the introduction of other functional groups such as amines. However, unlike for BODIPYs, a high concentration of the nucleophile is necessary for the reaction to proceed, as exemplified in the synthesis of complexes 15 and 16 prepared in neat propylamine and 1-aza-15-crown-5 respectively (Fig. 4). Unfortunately, in contrast with other $\operatorname{Re}(\mathrm{I}) \mathrm{dpm}$ complexes, ${ }^{30}$ the species prepared using this approach were all found to be non-emissive as a result of intramolecular charge transfer. 

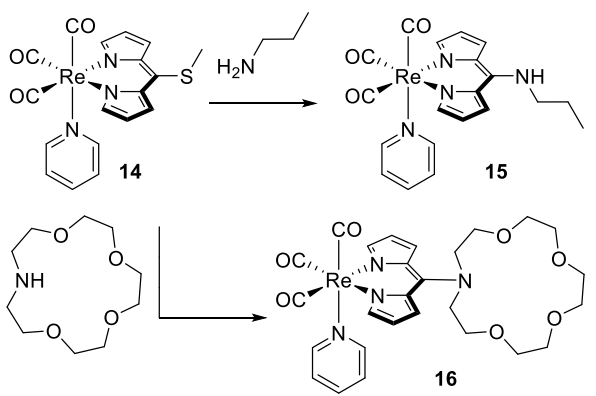

Fig. 4 Nucleophilic substitution on a thiomethyl appended Re(I) dpm complex as described by Telfer. ${ }^{28}$

\subsection{Reactivity at the $\alpha$ positions}

The examples presented above described functionalization at the meso position. The pyrrolic positions are also prone to derivatization. In particular, alkoxylation of the dpm backbone at the $\alpha$ position has been demonstrated to be activated by complexation. ${ }^{31}$ The group of Cohen reported that upon reaction of the benzonitrile-appended dipyrromethane 17 with DDQ (2,3-dichloro-5,6-dicyano-1,4benzoquinone) and the $\mathrm{Na}_{3} \mathrm{Co}\left(\mathrm{NO}_{2}\right)_{6}$ salt in a mixture of $\mathrm{MeOH}$ and $\mathrm{NEt}_{3}$, several compounds were concomitantly formed: the target homoleptic $\mathrm{Co}$ (III) complex $\mathbf{1 8}$, as expected, along with a heteroleptic $\mathrm{Co}$ (III) compound incorporating a dpm bearing a methoxy group at one $\alpha$ position 19 , as well as the corresponding functionalized free alkoxy-dpm ligand 20 (Fig. 5). The reaction was found to only proceed in the presence of the metal. The above-mentioned $\mathrm{Co}$ (III) salt gave the best yields, with $\mathrm{Mn}(\mathrm{OAc})_{2} 4 \mathrm{H}_{2} \mathrm{O}, \mathrm{FeCl}_{3} 6 \mathrm{H}_{2} \mathrm{O}$, and $\mathrm{Co}(\mathrm{py})_{4} \mathrm{Cl}_{2} \mathrm{Cl}$ found to be also effective, albeit to a lesser extent. Other alcohols such as ethanol, 1- and 2-propanol, benzyl alcohol could be employed for the alkoxylation, although with much lower yields. This type of reactivity, that had also been observed on a N-confused $\mathrm{Ni}$ porphyrin, ${ }^{32}$ was also reported for a ferrocene appended dpm and a 2,2'-bis-dpm bearing pentafluorophenyl groups, catalyzed by $\mathrm{FeCl}_{3} \cdot{ }^{33-34}$

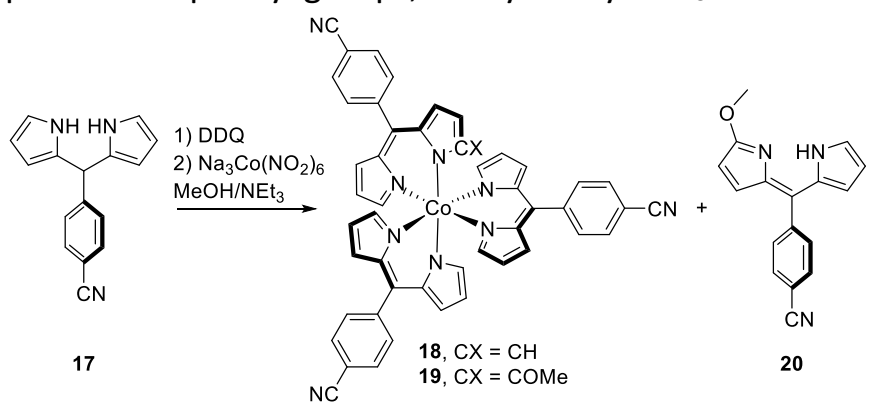

Fig. 5 Alkoxylation at the $\alpha$ position of a dpm as described by Cohen and coworkers. ${ }^{31}$

While $\alpha$-Me groups have been extensively employed for functionalization of $\mathrm{dpm}$ or BODIPY derivatives such as in Knoevenagel reaction, ${ }^{19,35}$ functionalization of dpm metal complexes at these sites remains scarce. Interestingly, Wagler and coworkers have studied the complexation of a $\mathrm{Si}(\mathrm{IV})$ cyclobutane complex based on a 1,1-bis(pyrrol-2-yl)ethene and have showed that this compound was prone to a ring opening leading to an attack of the methyl group in the $\alpha$ position of the $\mathrm{dpm} .^{36}$

\section{Templates for the formation of polypyrrolic derivatives}

The dpm scaffold has been employed as a precursor to polypyrrolic derivatives by taking advantage of the template nature of its metal complexes, thus arranging two dpm moieties in a preorganized fashion. Following this approach, a wide array of compounds has been prepared.

\subsection{Template complexes for the formation of [2]catenanes}

Since the seminal article by Sauvage and coworkers, ${ }^{37}$ metal templation has been extensively used for the elaboration of catenanes. ${ }^{38}$ While 2,2'-bipyridine and 1,10-phenanthroline derivatives have been extensively used for such purposes, the group of Bozdemir has taken advantage of the neutrality and 
organization of complexes of $\alpha$-functionalized dpm with divalent metals ( $\mathrm{Zn}(\mathrm{II}), \mathrm{Cu}(\mathrm{II}))$ to prepare a novel class of [2]catenane. ${ }^{39}$ Thus, complex 21 has been prepared (Fig. 6). It shows a distorted tetrahedral geometry resulting in the favorable arrangement of aryl groups at positions 1 and 9 bearing pendant allyl-terminated diethyleneglycol groups. Upon ring-closing metathesis of the latter moieties in the presence of Grubbs second generation catalyst, the closing of the two ligands hence intertwined is performed in 75\% yield leading to complex $\mathbf{2 2}$ (Fig. 6). Upon demetallation of 22, a [2]catenane incorporating two free dpms units is obtained; it can be further used for the preparation of a luminescent BODIPY [2]catenane.
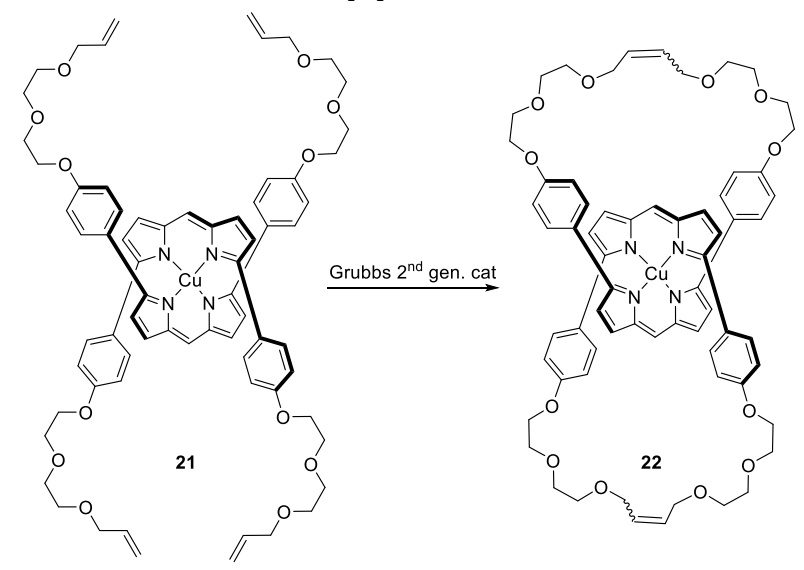

Fig. 6 Ring-closing metathesis for the formation of a [2]catenane precursor, as described by the group of Bozdemir. ${ }^{39}$

The $\mathrm{Zn}(\mathrm{II})$ analogue of $\mathbf{2 1}$ has also been prepared but no proper conditions for its demetallation could be found. It is worth noting that ring-closing metathesis was also used by Maeda for connecting strands of binuclear $\mathrm{Zn}$ (II) helicates based on functionalized 2,2'-bis-dpm ligands. ${ }^{40}$ These examples benefit from the prearrangement of the $\mathrm{dpm}$ ligands but do not fully exploit the intrinsic electronic impact of the metal present in the complex. This has been addressed in the development of a series of conjugated polypyrrolic derivatives.

\subsection{Precursors to $2, \mathbf{2}^{\prime}$-bis-dipyrrins}

Scott and coworkers have used $\mathrm{Ni}(\mathrm{dpm})_{2}$ complexes as templates for the formation of 2,2'-bis-dpm derivatives by oxidative formation of a CC bond owing to the close proximity of the ligands upon complexation as well as the Lewis acidity of $\mathrm{Ni}(\mathrm{II})$ cation. ${ }^{41}$ For example, dpm Ni complex $\mathbf{2 3}$ has been shown to convert to the 2,2'-bis-dpm analogue $\mathbf{2 4}$ upon treatment with an oxidant such as DDQ or $p$ chloranil (Fig. 7). Upon reaction, the two dpm chelates are conjugated and afford an environment to the metal center closer to square planar as demonstrated by ${ }^{1} \mathrm{H}-\mathrm{NMR}$ spectroscopy and by crystal structure determination by X-Ray diffraction. Another advantage of the use of $\mathrm{Ni}(\mathrm{II})$ for this process is the ease of demetallation of the resulting complex by treatment under acidic conditions thus yielding quantitatively the free $2,2^{\prime}$-bis-dpm ligand. While the original report described this process applied to phenyl and mesityl appended $\mathrm{Ni}$ (II) complex, it has been subsequently extended to a wide array of peripheral aromatic groups to afford ligands employed for the formation of more complex assemblies such as $\mathrm{Zn}(\mathrm{II})$ linear and circular helicates and macrocycles. ${ }^{40,42-45}$

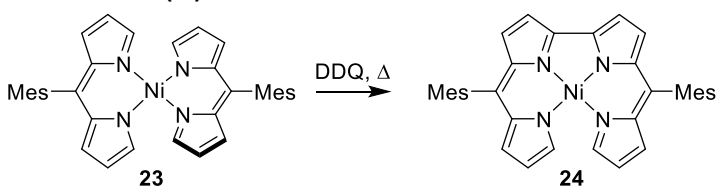

Fig. 7 Formation of a 2,2'-bis-dipyrrin complex upon reaction of DDQ with a $\mathrm{Ni}(\mathrm{dpm})_{2}$ template resulting in conjugation and planarization of the coordination environment, as reported by Scott et. $a l .{ }^{41}$ Mes $=$ Mesityl . 


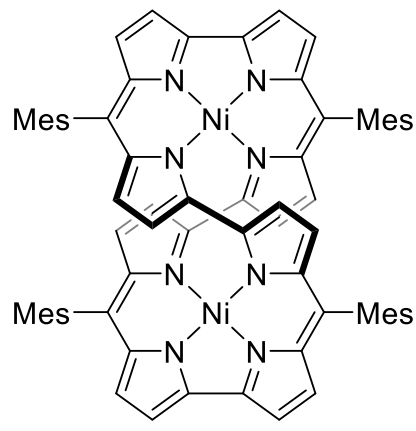

28

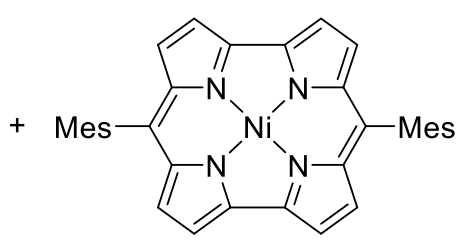

27

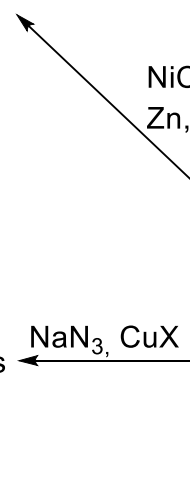

$\mathrm{NiCl}_{2} / \mathrm{PPh}_{3}$

$\mathrm{Zn}, \mathrm{DMF}, \Delta$

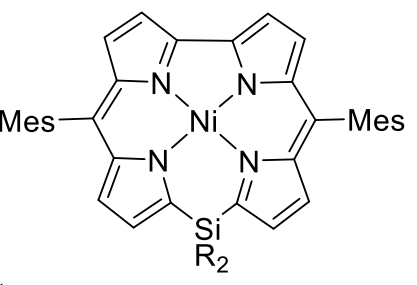

33, $\mathrm{R}=\mathrm{Et}, \mathrm{Ph}$
$\mathrm{R}_{2} \mathrm{SiH}_{2}$

$\mathrm{Pd}\left(\mathrm{PtBu}_{3}\right)_{2}$

$\mathrm{DABCO}$

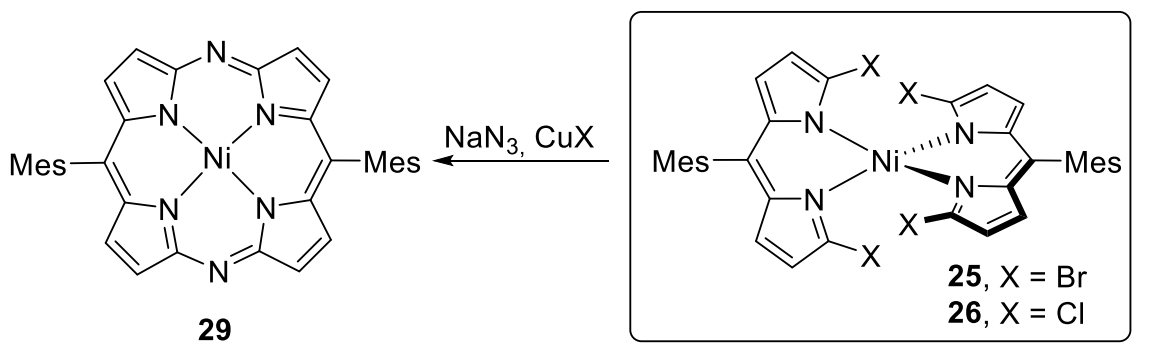

29
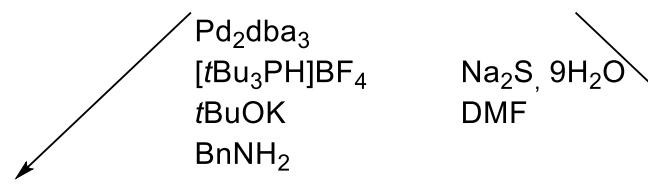
DMF

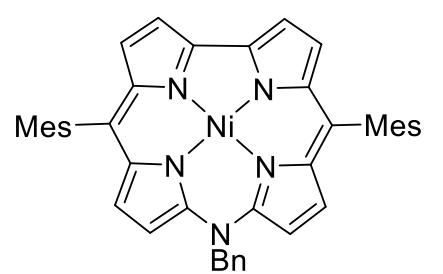

30

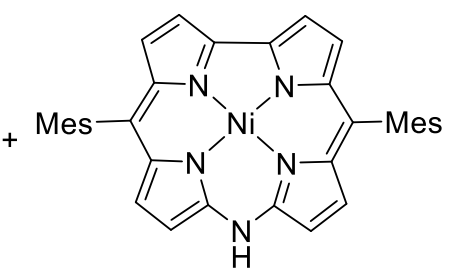

31

$+\quad 29$

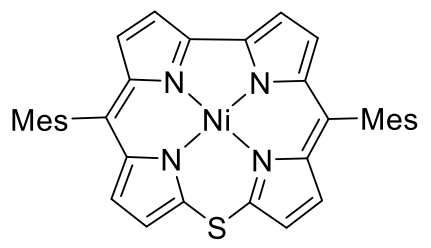

32

Fig. 8 Homoleptic Ni(II) complexes bearing $\alpha$-halides as precursors to tetra- and octa-pyrrolic systems. Mes $=$ Mesityl.

Interestingly, while 2,2'-bis-dpm complexes have been shown to allow macrocyclization towards porphynoids, ${ }^{46-47}$ metal dpm complexes can also be employed as templates for such processes. In particular, the homoleptic $\mathrm{Ni}$ (II) complexes $\mathbf{2 5}$ and $\mathbf{2 6}$ based on dpms bearing, respectively, either bromine or chlorine atoms at the $\alpha$ positions (Fig. 8) have been shown to undergo a diversity of transformations leading to valuable polypyrrolic derivatives. The group of Shinokubo has described that $\mathbf{2 5}$ could be readily converted to norcorrole $\mathbf{2 7}$ in $90 \%$ yield upon $\mathrm{Ni}(0)$ coupling. ${ }^{48}$ This efficient synthesis differs from the previously described preparation of an highly reactive Fe(III) analogue starting from a 2,2'-bis-dpm complex. ${ }^{49}$ It also allowed the complete characterization of such a unique antiaromatic species, ${ }^{50}$ the properties of which have been shown by theoretical calculations to originate from the dpm moieties within the macrocycle. ${ }^{51}$ Furthermore, it was later found that this reaction not only yields the norcorrole but also the octaphyrin(1.0.1.0.1.0.1.0) bis[Ni(II)] complex $28 .^{52}$ While the latter complex is obtained as a minor product with this process, reaction of the $\mathrm{Pd}(\mathrm{II})$ analogue of $\mathbf{2 5}$ under the $\mathrm{Ni}(0)$ homocoupling conditions affords the Pd version of $\mathbf{2 8}$, in $\mathbf{3 5 \%}$ yield. The intramolecular reaction was rationalized to be favored over the intermolecular one in this case as a result of 
longer $\mathrm{Pd}-\mathrm{N}$ distances in the $2,2^{\prime}$-bis-dpm intermediate leading to the remaining reactive $\alpha-\mathrm{CBr}$ groups being further apart.

While it has been recognized that metal complexes of $\beta$-substituted $\mathrm{dpm}$ bearing $\alpha-\mathrm{Br}$ atoms were prone to the formation of 5,15-diazapophyrins upon reaction with sodium azide, ${ }^{53-55}$ Matano and coworkers showed that the unsubstituted analogue could be prepared from $25 .{ }^{56}$ Reaction with sodium azide and $\mathrm{Cu}(\mathrm{I})$ halide salts affords 29 in yields above $80 \%$. Interestingly, when the reaction is performed in the absence of $\mathrm{Cu}(\mathrm{l})$ salt, the yield drops and pyridazine-fused diazacorrinoids are also formed. The reaction was found to be also efficient using the $\mathrm{Cu}(\mathrm{II})$ analogue of $\mathbf{2 5}$ and recently the $\mathbf{Z n}$ (II) one. ${ }^{57,58}$ Interestingly, it has been reported that $\mathbf{2 6}$ forms $\mathbf{2 9}$ only as traces upon BuchwaldHartwig amination. Under these conditions, the major products are actually azacorroles $\mathbf{3 0}$ and $\mathbf{3 1} .^{59}$ Compound $\mathbf{3 1}$ is the analogue of $\mathbf{3 0}$, where the benzyl group has been cleaved during the synthesis, thus bearing an acidic $\mathrm{N}-\mathrm{H}$ that can be used for further acylation of the azacorrole.

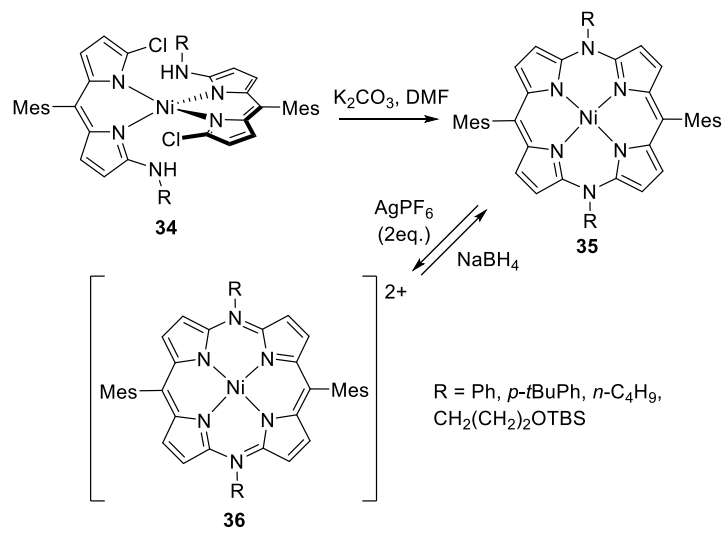

Fig. 9 Template synthesis of redox-active 5,15-diazaporphynoids as reported by the group of Matano. ${ }^{60-62}$ Mes $=$ Mesityl.

Introduction of nitrogen atoms has been used as a strategy to form 5,15-diazaporphynoids. The interest in these compounds stems from their representing $20 \pi$-electron redox-switchable derivatives. Thus, the group of Matano has used $\mathrm{Ni}$ (II) complexes $\mathbf{3 4}$ based on dissymmetrical dpm ligands as precursors to such 5,15-diazaporphynoids $\mathbf{3 5}$ upon treatment under basic conditions (Fig. 9).$^{60}$ This double nucleophilic substitution has been shown to operate with aromatic and alkyl groups on the nitrogen atom as well as on $\mathrm{Zn}(\mathrm{II})$ and $\mathrm{Cu}(\mathrm{II})$ complexes albeit with a modification of the nature of the base employed. ${ }^{61-62}$ Starting from heteroleptic complexes, dissymmetrical 5,15-diazaporphynoids could also be obtained. ${ }^{63-64}$ These compounds were shown to be oxidized by silver salts to produce reversibly the $19 \pi$-electron radical cation and the $18 \pi$-electron dication, $\mathbf{3 6}$. All these compounds are stable and can be fully characterized allowing an assessment of the effect of redox state on their photophysical properties.

Introduction of sulfur atoms into the tetra-pyrrolic scaffold has been reported by the group of Shinokubo which described that $\mathrm{Ni}(\mathrm{II})$ complex $\mathbf{2 6}$ reacted with sodium sulfide to produce 10thiacorrole 32 in $41 \%$ yield (Fig. 8). ${ }^{65}$ Interestingly, the same reaction using the $\mathrm{Zn}$ (II) analogue of 26 afforded the 5,15-dithiaporphyrin derivative instead, that was shown to be much more distorted than for the planar aromatic 32. The difference in reactivity is assumed to proceed from the size of the metal cation. The intermediate $\mathrm{Ni}$ (II) 5,15-dithiaporphyrin is less folded at the sulfur atoms thus leading to two $\alpha$-carbon atoms being close for further reaction towards the formation of $\mathbf{3 2}$ via an episulfide species. The group of Bröring has shown that a $\mathrm{Cu}(\mathrm{II})$ complex based on a $\alpha$-bromo substituted dpm can lead to a series of 10-heterocorroles incorporating an oxygen, a sulfur or a selenium atom. ${ }^{66} \mathrm{It}$ was described that the resulting $\mathrm{Cu}(\mathrm{II})$ compounds obtained could be readily demetallated to access the free base ligand. The family of 10 -heterocorroles was extended to 10 -silacorroles by the group of 
Hiroto and Shinokubo who reported that complex $\mathbf{2 5}$ could be silylated to afford $\mathbf{3 3}$ in $\mathbf{2 0 - 2 2 \%}$ yield upon reaction with a silane (Fig. 8) ${ }^{67}$ The $\mathrm{Ni}$ (II) cation could be removed to produce the free base that could be metallated by $\mathrm{Zn}(\mathrm{II})$. These latter derivatives featured emission in the near-infra-red, in $\mathrm{CH}_{2} \mathrm{Cl}_{2}$ solution and their electronic properties are impacted by the nature of the substitutents on the $\mathrm{Si}$ (IV) atom.

Metal dpm complexes thus appear as efficient templates for the preparation of nor-/hetero-corroles and other porphynoids and can thus be considered in the toolbox of available synthetic methods for the preparation of such pyrrolic species. ${ }^{17,68}$ In these cases, the reaction takes place on the dpm scaffold. Interestingly, the dpm ligands have also been employed for the preparation of complexes featuring reactivity at the metal center, as described in the following sections.

\section{Complexes for $\mathrm{C}-\mathrm{H}$ activation/amination}

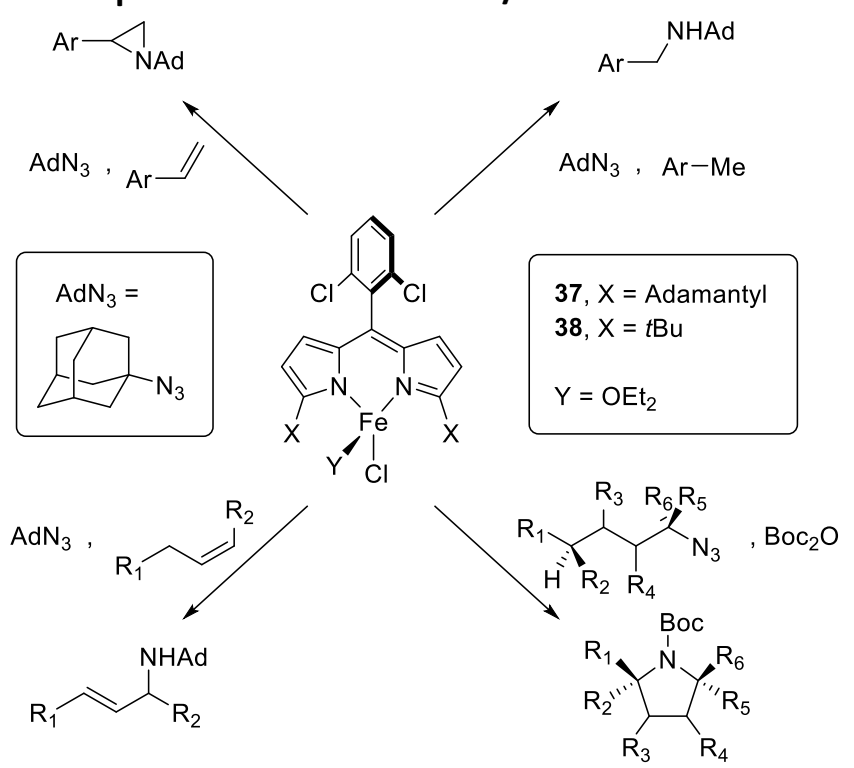

Fig. $10 \mathrm{C}-\mathrm{H}$ bond amination based on Fe(II) dpm complexes used in $10-20 \mathrm{~mol} \%$, as described by the group of Betley. ${ }^{71-72,73,75}$

Betley and coworkers have reported that a Fe(II) dpm complex with mesityl groups in the $\alpha$ positions is prone to intramolecular $\mathrm{C}-\mathrm{H}$ amination at the ligand itself in the presence of an arylazide. ${ }^{69} \mathrm{It}$ was shown that modification of the functional groups on the bis-pyrrolic backbone not only affects the electronic properties of the complexes ${ }^{70}$ but also can make the reaction proceed in an intermolecular fashion, and even catalytically (Fig. 10). ${ }^{71-72}$ Thus complex 37 bearing adamantyl moieties at the $\alpha$ positions was demonstrated to be efficient to catalyze benzylic amination and aziridination, while $\mathbf{3 8}$ bearing $t$-butyl groups was efficient for allylic amination. These reactions were shown to proceed with substrates comprising either electron-withdrawing or donating units. The unique reactivity of these species stems from the formation of a high-spin Fe(III) complex coupled to a nitrogen-based radical, upon reaction with an azide, thus affecting the Fe- $\mathrm{N}$ bond. In addition to the spin/radical character, the sterics of the ligand and of the azide is important, as shown in the preference of allylic amination over aziridination with aliphatic olefins. Remarkably, with aliphatic azides, complex $\mathbf{3 7}$ catalyzes the formation of pyrrolidines. ${ }^{73}$ The product inhibition associated with the formation of these heterocycles was circumvented by using $\mathrm{Boc}_{2} \mathrm{O}$ as an in situ protecting agent. The mechanism of this catalysis has been investigated experimentally as well as theoretically. ${ }^{74}$ It occurs first via exchange of the labile ligand on the metal center (OEt ${ }_{2}$ in Fig 10) followed by oxidation of the $\mathrm{Fe}(\mathrm{II})$ to $\mathrm{Fe}(\mathrm{III})$ center and formation of the nitrene radical, concomitant with the release of dinitrogen. The subsequent hydrogen abstraction and radical rebound afford the desired $\mathrm{N}$-heterocycle. It is worth noting that the latter rebound process shows no energetic barrier hence making the hydrogen abstraction the rate limiting step, consistent with the observation that there is a retention of stereochemical information during 
the process thus leading to diastereoisomers. This was further taken advantage of to improve the diastereoselectivity of the amination. ${ }^{75}$ To that aim, a mesityl group was introduced at the meso position and phenoxide was substituted for the chloride as ancillary anionic ligand, modifying the electronics ${ }^{76}$ and the sterics of the catalytic pocket. It was further shown that not only Fe iminyl complexes can induce $\mathrm{C}-\mathrm{H}$ amination but so do the reduced Fe imido counterparts, albeit with a lower rate (see $\mathbf{4 2}$ and $\mathbf{4 3}$ in Fig. 11). ${ }^{77-79}$ Furthermore, Fe(I) complex $\mathbf{3 9}$ was also demonstrated to react with nitroxyl radicals yielding nitroxido compounds that activate $\mathrm{C}-\mathrm{H}$ bonds. ${ }^{80}$
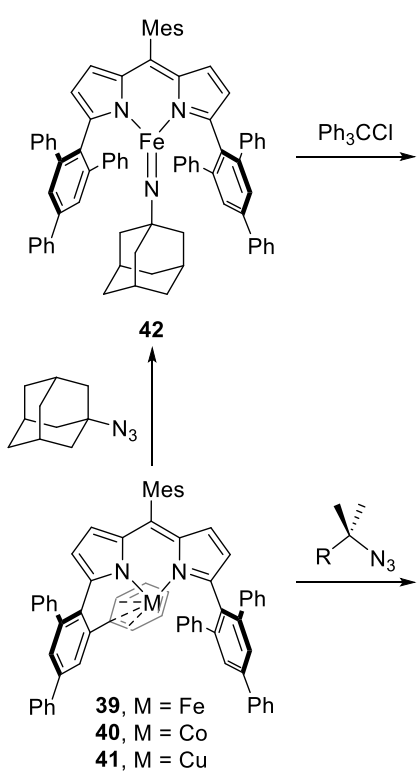

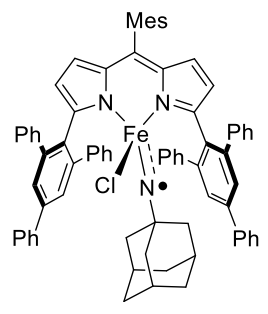

43

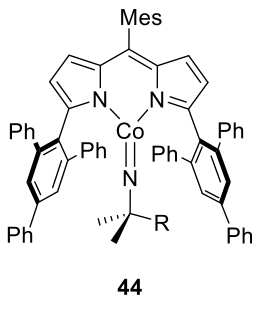

Fig. $11 \mathrm{Fe}(\mathrm{I}), \mathrm{Co}(\mathrm{I}), \mathrm{Cu}(\mathrm{I})$ complexes used for $\mathrm{C}-\mathrm{H}$ activation/amination as described by Betley and coworkers. ${ }^{79}, 82,85$ Mes $=$ Mesityl.

The Co(I) analogue, 40, reacts with azides to form Co(III) imido species such as $\mathbf{4 4}$ (Fig. 11) as observed for the iron species. ${ }^{81}$ With such complex, $\mathrm{C}-\mathrm{H}$ amination towards pyrrolidine is competing with the formation of tetrazido compounds. ${ }^{82}$ The latter compounds are catalytically inactive. To avoid their formation and favor amination, the group of Betley has studied the reaction of $\mathbf{4 0}$ with benzylic derivatives in order to kinetically facilitate the bond activation step and has employed pyridine as a ligand to hamper generation of tetrazido based species. This approach proved successful with excellent yields and rates of amination for this system. An alternative strategy relied on modifying the steric hindrance of the groups at the $\alpha$-positions by using trityl moieties. With such complex, amination was shown to be highly effective while limiting the formation of tetrazene but also led to a modification of the arrangement of the imide group during the process facilitating the hydrogen atom abstraction. ${ }^{83}$ This family of complexes prepared by reaction of the Li(dpm) intermediate ${ }^{84}$ with the desired metal cation followed by reduction was extended to the $\mathrm{Cu}(\mathrm{I})$ species $\mathbf{4 1}$ (Fig. 11). ${ }^{85}$ This compound is also active for $\mathrm{C}-\mathrm{H}$ amination of cyclohexene, cyclohexane and toluene in the presence of stoichiometric amount of electron-poor aryl azide with yields up to $77 \%$. With a modified dpm scaffold bearing highly sterically demanding units in positions 1 and 9, a dinitrogen adduct could be isolated and fully characterized. Interestingly, when a Pacman structure was constructed using two dpm chelates bridged by a dimethylxanthine unit (vide infra), the resulting binuclear $\mathrm{Cu}$ complexes were demonstrated to form imide compounds upon reaction with aryl azides that could be reduced to the iminyl species. ${ }^{86}$ However, neither nitrene nor hydrogen atom abstraction were observed with these complexes. Recently, a Ni(I) analogue based on a dpm with a pentafluorophenyl group and adamantyl moieties at the meso and $\alpha$ positions respectively has been shown to also form an iminyl complex upon reaction with 1-adamantylazide, prone to further reaction with toluene to afford an imine. ${ }^{87}$ 


\section{Reactivity of oxygen based species}

In addition to compounds for nitrene transfer, oxo and oxygen adducts of dpm metal complexes have been described and their reactivity has been explored. For example, the above-mentioned $\mathrm{Cu}(\mathrm{I})$ complex $\mathbf{4 1}$ reacts with dioxygen to form compound $\mathbf{4 5}$ that has been characterized in solution and in the crystalline state (Fig. 12). ${ }^{88}$ This complex was shown to induce hydrogen atom abstraction upon reaction with 1,4-cyclohexadiene. Furthermore, this latter process was observed coupled to oxygen atom transfer when $\mathbf{4 5}$ was treated with 2,4,6-tri-tert-butylphenol for example. The model reaction with a radical trap suggests a rearrangement of the $\mathrm{O}_{2}$ binding mode to a terminal one leading to these two processes. Interestingly, analogous reaction with phenol led to the generation of hydrogen peroxide and formation of the phenolate Cu complex. Finally, oxygen atom transfer was also observed upon reaction with triphenylphosphine (Fig. 12).

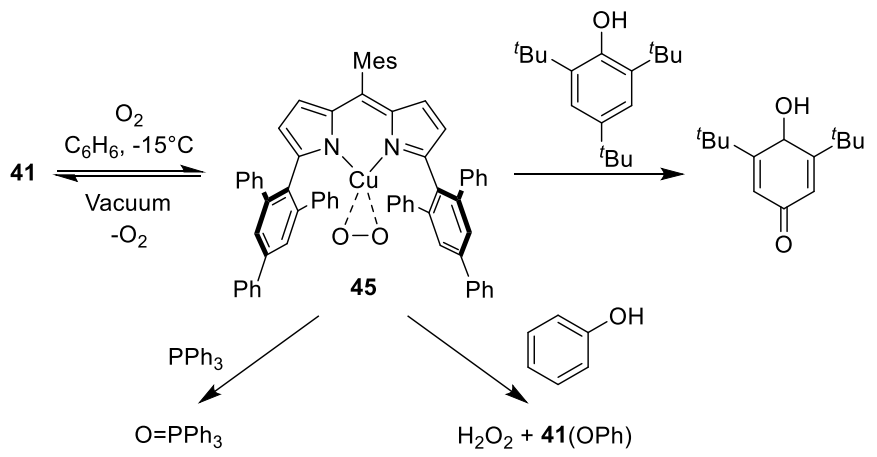

Fig. 12 Reactivity of 45 , the oxygen adduct of 41 , as described by the group of Betley. ${ }^{88}$

The $\mu$-oxo binuclear Fe complex, 46, based on a Pacman bis-dpm ligand was shown to convert into the $\{\mathrm{Fe}(\mathrm{III})\}_{2}, 47$, and mixed valent $\{\mathrm{Fe}(\mathrm{II}) \mathrm{Fe}(\mathrm{III})\}, 48$, form (Fig. 13). ${ }^{89}$ These oxo complexes were investigated for their basicity towards the formation of $\mu$-hydroxide analogues. Compound $\mathbf{4 8}$ was found to not react with weak $\mathrm{C}-\mathrm{H}$ bonds but it was rather revealed that this species was sensitive to water.

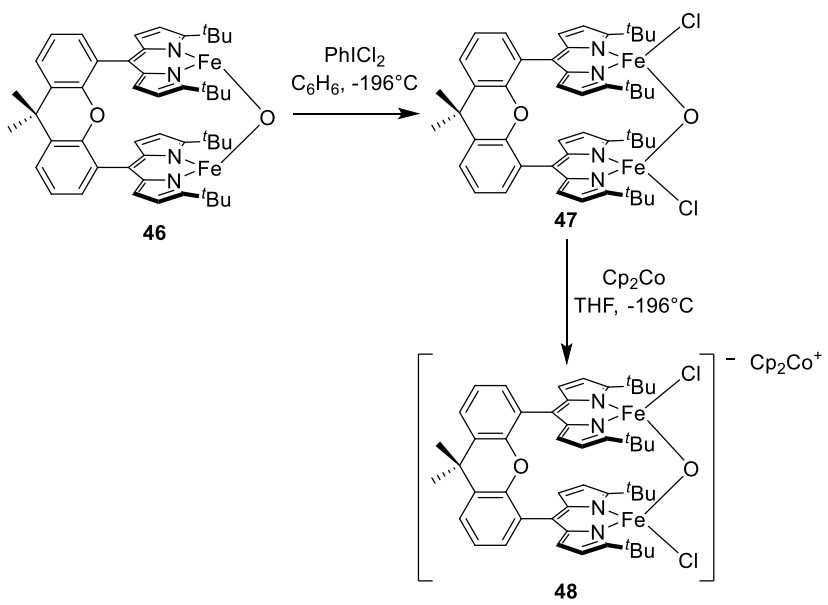

Fig. 13 Binuclear $\mu$-oxo bridge Fe complexes described by Betley and coworkers. ${ }^{89}$

It is worth noting that the group of Love also reported a $\mu$-oxo binuclear Fe(III) complex, 49, analogous to 47 (Fig. 14).$^{90}$ The reactivity of this compound has, to the best of our knowledge, not been described. The difference between $\mathbf{4 7}$ and $\mathbf{4 9}$ is that the latter comprises two unbridging mono-dpm ligands featuring imine groups at the $\alpha$ positions. Katayev and coworkers have similarly appended the $\mathrm{dpm}$ scaffold with imines showing that the formally $\mathrm{Pd}(0)$ and $\mathrm{Pt}(0)$ complexes $\mathbf{5 0}$ (Fig. 14) were prone to dioxygen activation leading to complexes with modification of the functional groups at the $\alpha$ or meso positions; the imine was shown to convert to a carboxylate unit in the case of the Pd compound, for 
example. ${ }^{91}$ The dpm-diimine backbone was also shown to complex not only uranyl but more generally to stabilize the uranium cation in the oxidation states IV, $\mathrm{V}$ and IV as illustrated for $\mathbf{5 1}$ (Fig. 14). ${ }^{92-93}$ The stabilization of these different redox states involves the non-innocent nature of the ligand allowing its reduction and the capacity to use the axial oxygen atom upon reaction with $\left[\mathrm{TiCp}_{2} \mathrm{Cl}\right]_{2}$ or borane functionalization. Interestingly, with $\mathrm{dpm}$ unfunctionalized at the $\alpha$ positions, the uranyl complexes were not studied for such reactivity but were demonstrated to be emissive. ${ }^{94}$ The group of BowmanJames has reported that the binuclear $\mathrm{Mn}$ (II) complex $\mathbf{5 2}$ based on two dpm- $\alpha$-diimine moieties bridged by flexible propyl groups features mono-oxygenase like activity. In the crystal structure of this compound, the $\mathrm{Mn}$ (II) cations are bridged by an acetate anion and their coordination sphere is completed by either a water molecule or a chelating acetate (Fig. 14). The epoxidation of either cyclohexene or stilbene could be performed using this complex in yields up to $40 \% .{ }^{95}$ It was later demonstrated that $\mathbf{5 2}$ also shows a catalase-like activity thus catalyzing the disproportionation of $\mathrm{H}_{2} \mathrm{O}_{2} \cdot{ }^{96}$ The bound water and acetate anions were demonstrated to play an active part in the reactivity of this complex.
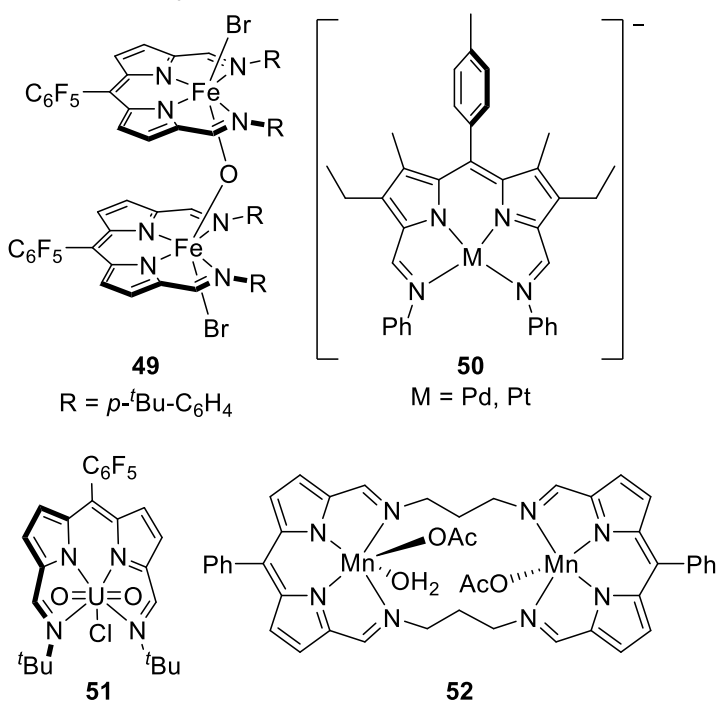

Fig. 14 Reactive complexes $49-52$ based on the dpm $\alpha$-diimine scaffold. Note that, in the crystal structure of 52, one of the acetate anions is bridging the two $\mathrm{Mn}$ (II) cations.

\section{The dipyrrin-bisphenol scaffold}

Another class of $\alpha$-functionalized dpm has been intensively investigated over the past few years: the $\mathrm{dpm}$-bisphenol (dpmPhO), bearing phenol units at positions 1 and 9 . This scaffold is a hybrid between the porphyrin and the salen backbones and bears some analogy with corroles. ${ }^{97}$ Described in the $1970 s^{98}$ it was used for the preparation of the corresponding luminescent boron complex ${ }^{99}$ and then for a series of emissive metal complexes. ${ }^{100-104}$ Interestingly, this type of ligand was shown to have a non-innocent character as the $\mathrm{Co},{ }^{105-107} \mathrm{Ni}^{105} \mathrm{Cu}^{108}$ and $\mathrm{Pt}^{109}$ complexes can be formulated (dpmPhO) ${ }^{2-}$ - $M$ (II) on the basis of electrochemical data, single-crystal X-ray diffraction, EPR and UV-visible spectroscopies combined with theoretical calculations. With trivalent metal cations such as $\mathrm{Au}(\mathrm{III})$, the complex is better described as $(\mathrm{dpmPhO})^{3-} \mathrm{Au}(\mathrm{III})$ with an electrochemical behavior different from the one of the corrole analogues as reduction involves both the metal center and the ligand. ${ }^{110}$ Several complexes of $\mathrm{dpm}$-bisphenolate have been investigated for their reactivity, in particular $\mathrm{Mn}$ (III) compounds (Fig. 15). 


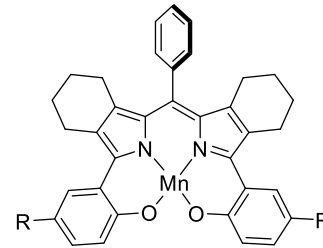

53, $\mathrm{R}=\mathrm{H}, \mathrm{Me}, \mathrm{F}$

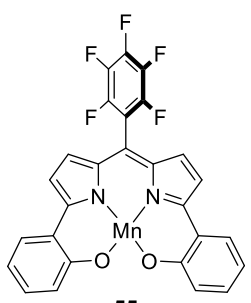

55

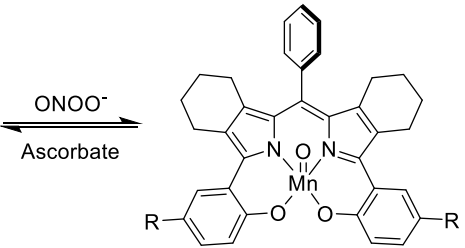

a)

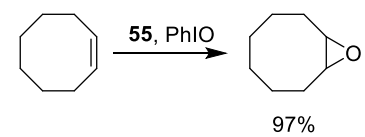

b)
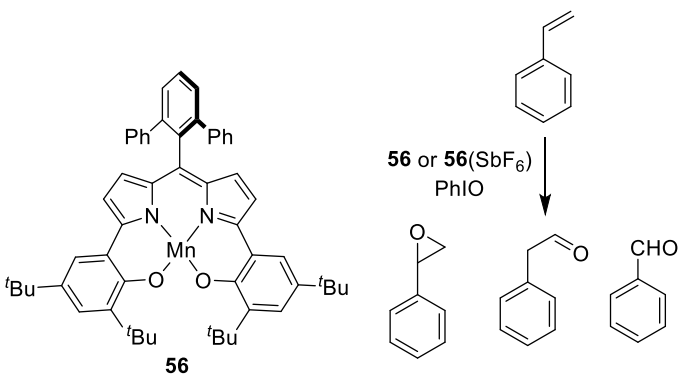

$\mathbf{5 6}\left(\mathrm{SbF}_{6}\right)$

c)

Fig. 15 Reactivity of $\mathrm{Mn}(\mathrm{dpmPhO})$ complexes.

Since $\mathrm{Mn}(\mathrm{III})$ porphyrin and corroles have been shown to decompose peroxynitrite, ${ }^{111-112}$ the group of Neumann has investigated the reactivity of complex $\mathbf{5 3}$ towards this oxidant (Fig 15a). ${ }^{113}$ This high-spin $\mathrm{Mn}(\mathrm{III})$ compound was demonstrated, by absorption spectroscopy and LC-MS, to convert to $\mathrm{Mn}(\mathrm{V}) \mathrm{O}$ complex $\mathbf{5 4}$ in the presence of peroxynitrite. This behaviour was further confirmed by the ability of $\mathbf{5 3}$ to inhibit the arylboronic oxidation by peroxynitrite as well as hyperalgesia in rats. Using a similar scaffold, the groups of Andrioletti and Aukauloo have prepared $\mathbf{5 5}$ and studied its catalytic activity for the epoxidation of alkenes (Fig. 15b). ${ }^{114}$ This compound, present as a dimer in the crystalline state, is in a monomeric form in solution. In acetonitrile, a yield up to $97 \%$ has been observed for the epoxidation of cyclooctene in the presence of iodosylbenzene, PhIO. The group of Thomas has expanded this family of compounds by preparing $\mathbf{5 6}$ (Fig. 15c) that bears $t$ Bu group on the phenolic moieties and additional phenyl units at the meso positions, hence preventing dimerization. ${ }^{115}$ This complex catalyzes the epoxidation of styrene with yields up to $31 \%$ with small amounts of phenylacetaldehyde and benzaldehyde as additional products. Interestingly, they have investigated the redox properties of this compound and have isolated and characterized the oxidized species $(56)^{+}\left(\mathrm{SbF}_{6}\right)^{-}$, featuring a $\mathrm{Mn}(\mathrm{III})$ center coupled to the ligand in its radical form. This oxidized species features a different activity towards styrene, since it does not lead to the formation of epoxide but rather to phenylacetaldehyde (Fig. 15c). Furthermore, $(56)^{+}\left(\mathrm{SbF}_{6}\right)^{-}$was found to catalyze the antiMarkovnikov isomerization of styrene oxide to phenylacetaldehyde. The group of Thomas also reported the properties of 57, the $\mathrm{Cu}(\mathrm{II})$ analogue of 56 (Fig. 16). ${ }^{108}$ In this complex, the metal center is in the divalent state and the ligand in its radical form. Compound $\mathbf{5 7}$ catalyzes the oxidation of alcohols under aerobic condition and in the presence of a base. Derivatives such as benzylalcohol, 1and 2-phenylethanol were converted to the corresponding aldehydes (Fig. 16). Though with a smaller TON, the conversion of the latter unactivated primary alcohol is worth noting. 


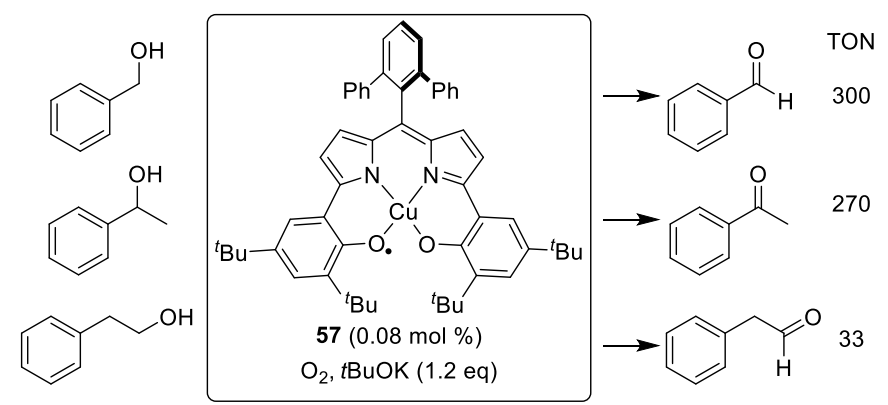

Fig. 16 Oxidation of alcohols catalyzed by $\mathrm{Cu}(\mathrm{II})$ complex $\mathbf{5 7}$, as described by the group of Thomas. ${ }^{108}$ TONs are given after $\mathbf{2 4}$ hours of reaction. Only one of the canonical forms of $\mathbf{5 7}$ has been presented for clarity.

Nozaki and coworkers have reported complexes $\mathbf{5 8}$ and $\mathbf{5 9}$ based on a similar ligand with tetravalent metal cations Ti(IV) and Ge(IV), respectively (Fig. 17). ${ }^{116}$ The coordination sphere of the metal center is completed by a chloride anion as well as a THF molecule in the case of $\mathbf{5 8}$. Both compounds catalyze the copolymerization of propylene oxide with $\mathrm{CO}_{2}$ at $60^{\circ} \mathrm{C}$ in the presence of $[\mathrm{PPN}] \mathrm{Cl}$ to yield poly(propylene carbonate) and propylene carbonate (PPN = bis(triphenylphosphine)iminium). The selectivity towards the polymer could be tuned by modifying the number of equivalents of [PPN]Cl. The $\mathrm{Zr}$ (IV) and Sn(IV) analogues were found to be less efficient in this catalysis. In a following report, the same group has provided mechanistic insights concerning the selectivity of these catalysts towards poly(propylenecarbonate) (PPC) over poly(propyleneoxide) (PPO) or propylene carbonate. ${ }^{117}$ This has led to the design of novel Ge(IV) catalysts, analogues of $\mathbf{5 9}$ where a hydrogen atom or a methoxy group substitutes for the $t$-butyl moiety at the para position of each phenolic moiety. It was thus demonstrated that the selectivity as well as the TOF could be rationally modulated by modifying these functional groups.

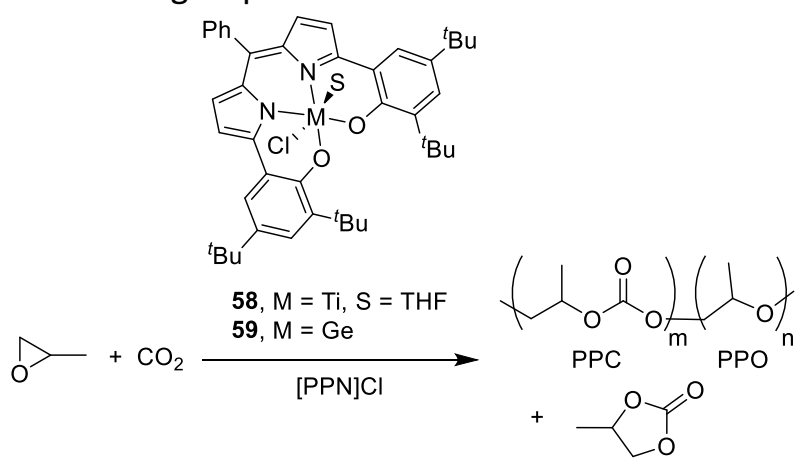

Fig. 17 Copolymerization of propylene oxide with $\mathrm{CO}_{2}$ catalyzed by Ti(IV) and $\mathrm{Ge}(\mathrm{IV})$ complexes $\mathbf{5 8}$ and 59, as described by Nozaki and coworkers. ${ }^{116}$

\section{Reactivity of $\mathbf{M g}$ (II) and AI(III) complexes}

Other dpm complexes have also been explored for polymerization purposes. Indeed, Chisholm et al. have reported $\mathrm{Mg}$ (II) complex 60 based on a tris-mesityl dpm (Fig. 18). ${ }^{118}$ This ligand was considered in light of its sterically demanding structure and low lability in order to modify the reactivity of the resulting Grignard reagent and, in particular, to prevent its involvement in the Schlenk equilibrium. The compound was described to react with alcohols, leading to a kinetic replacement of the alkyl group ( $n$-butyl in this case) and to form amides upon reaction with amines. Furthermore, it was demonstrated that the complex could act as an initiator for the ring opening polymerization of lactide and $\varepsilon$ caprolactone thus producing polylactide and polycaprolactone, respectively (Fig. 18). The solvent, either THF or $\mathrm{CH}_{2} \mathrm{Cl}_{2}$, was found to have an influence on the formation of heterotactic polylactide, with a more important stereocontrol in non-coordinating media. The role of the $\mathrm{dpm}$ is crucial in this 
observation. Interestingly, the specific sterics of this particular ligand was recently taken advantage of to isolate and identify a magnesium isocyanide compound and a germylene monochloride species. ${ }^{119-}$ 120

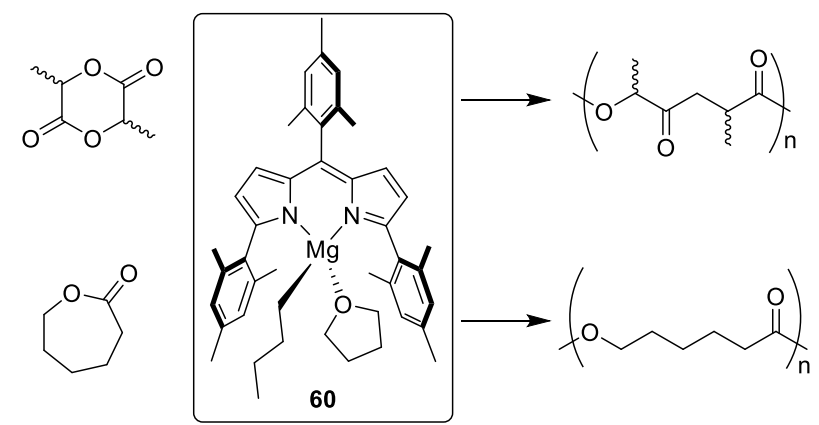

Fig. $18 \mathrm{Mg}$ (II) complex 60 as initiator of ring opening polymerization of lactide (top) and $\varepsilon$-caprolactone (bottom) as described by Chisholm et al. ${ }^{118}$

The group of Mason has investigated the ring-opening polymerization activity of $\mathrm{Al}(\mathrm{III})$ analogues of 60, with a phenyl at the meso position and either alkoxide or amide ligands. ${ }^{121-122}$ However, polymerization of $\varepsilon$-caprolactone was observed with rather poor conversion, as a result of the sterics imposed by the dpm ligand. Also, decomposition of the dimethylamide complex in the course of the catalysis was suggested.

\section{8. $\mathrm{Rh}(\mathrm{I}) / \mathrm{Rh}(\mathrm{III})$-based catalysts}

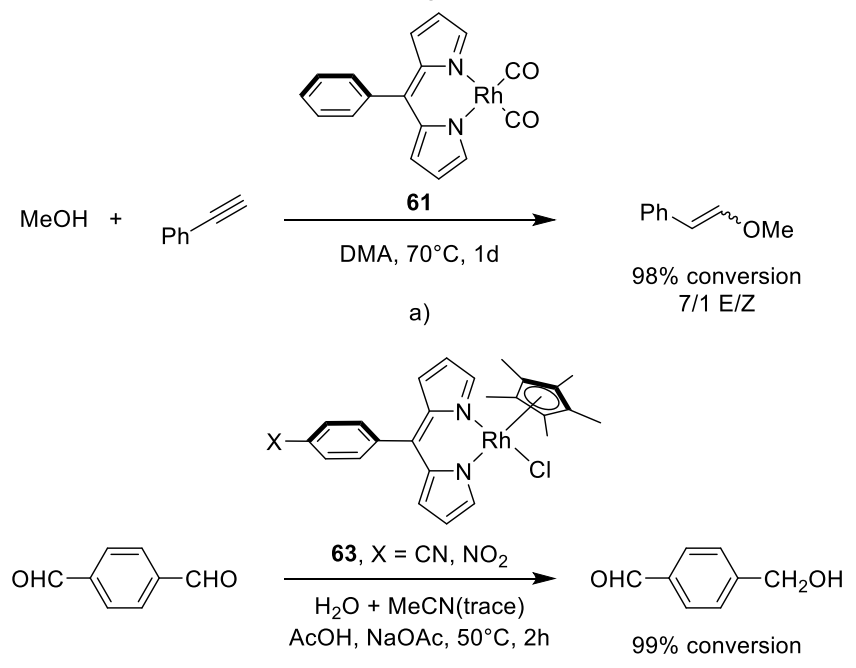

b)

Fig. 19 Reactions catalyzed by $\mathrm{Rh}(\mathrm{I})$ or $\mathrm{Rh}(\mathrm{III}) \mathrm{dpm}$ complexes.

Compounds incorporating Rh are widely explored in the literature for their reactivity. ${ }^{123-124}$ While a $\mathrm{Rh}(\mathrm{I}) \mathrm{dpm}$ complex has been described in $1974,{ }^{125}$ the catalytic activity of such species has been investigated much later. Messerle and coworkers reported Rh(I) complex 61 (Fig. 19a) active for the catalytic hydroalkoxylation of phenylacetylene and $\mathrm{MeOH} .{ }^{126}$ The reaction with $1 \mathrm{~mol} \%$ of 61 in $\mathrm{N}, \mathrm{N}$ dimethylacetamide (DMA) proceeded with a conversion of $98 \%$ and a clear preference for the $E$ product. Interestingly, the substrate scope was found to be wide, since neither electron-donating nor electron-withdrawing group in the para position of the aromatic unit of the substrate impacted negatively the conversion rate. The favored formation of the $E$ isomer of (2-methoxyvinyl)benzene was rationalized by less steric hindrance between the methoxy and phenyl group in the trans arrangement by DFT calculations. ${ }^{127}$ This theoretical investigation also suggests that DMA facilitates the addition of 
$\mathrm{MeOH}$ and that the mechanism involves a vinyl $\mathrm{Rh}(\mathrm{III})-\mathrm{H}$ hydride intermediate. Khoroshutin and coworkers also described the activity of a $\mathrm{Rh}(\mathrm{I})$ compound based on dpm albeit with the bis-pyrrolic chelate not at the rhodium center. ${ }^{128}$ The heterometallic catalyst was obtained by combination of (acac) $\mathrm{Rh}(\mathrm{CO})_{2}$ with 62, the analogue of $\mathrm{Co}(\mathrm{III})$ complex 1 where $\mathrm{X}=\mathrm{PPh}_{2}$ (Fig. 2). This compound led to the formation of a mixture of isomers of aldehyde upon hydroformylation of 1-octene.

The group of Pandey has reported a series of organometallic $R$ (III), $\operatorname{Ir}(\mathrm{III})$ and $\mathrm{Rh}$ (III) complexes incorporating dpm ligands focusing on their biological activity, supramolecular assembly as well as their catalytic activity. ${ }^{129-134}$ In particular, $\mathrm{Rh}$ (III) complexes of type $\mathbf{6 3}$ (Fig. 19b) were shown to catalyze the transfer hydrogenation of terephthaldehyde leading to the mono-reduced derivative 4hydroxymethylbenzaldehyde with complete conversion. ${ }^{130}$ Interestingly, the $\operatorname{Ir}(I I I)$ analogues of 63 were found to be less efficient for this process. A similar reactivity was observed for compounds where the metal center ( $\mathrm{Ru}(\mathrm{II}), \mathrm{Ir}(\mathrm{III})$ or $\mathrm{Rh}(\mathrm{III}))$ is coordinated to a peripheral pyridyl unit of a dipyrromethene ligand rather than by the dpm chelate itself. ${ }^{131}$

\section{Pd(II) based catalysts}

The Suzuki-Miyaura cross-coupling is an important tool in organic chemistry with active research in the development of new palladium catalysts. ${ }^{135}$ Surprisingly, while homo- and heteroleptic Pd(II) dpm complexes have been extensively investigated, ${ }^{33,136-145}$ only one report described the potential of these compounds for $\mathrm{C}-\mathrm{C}$ bond formation. ${ }^{140}$ Mono- and bi-nuclear heteroleptic complexes 64 and $\mathbf{6 5}$ (Fig. 20) were shown to be active for the cross-coupling of arylbromides with phenylboronic acid. Yields were found to reach up to $81 \%$ with aromatic substrates bearing an electron-withdrawing substituent and when using the binuclear species. Compound 64 gave a conversion rate around $c a$. $70 \%$. Whereas the analogue of 65 with an azaBODIPY moiety substituting for one Pd(II) complex has been reported, its catalytic activity has not been described. ${ }^{141}$
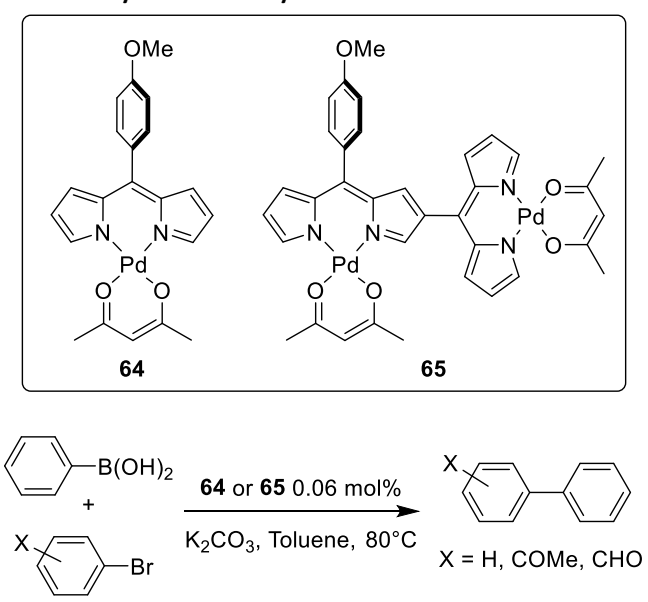

Fig. 20 Pd(II) based Suzuki Miyaura catalysts 64 and 65, described by Ravikanth and coworkers. ${ }^{140}$

\section{Heterogeneous catalysts}

So far, all the examples described herein have been homogeneous catalysts. Interestingly, the group of Liras has developed an heterogeneous porous polymer as a visible light photocatalyst for the azaHenry reaction (Fig. 21). ${ }^{146}$ Following an earlier report of an all-BODIPY porous polymer, ${ }^{147}$ removal of boron led to deprotected dpm available for complexation of the $\left[R u(b p y)_{2}\right]^{2+}$ fragment (bpy $=2,2^{\prime}$ bispyridine). Whereas heteroleptic $\left[R u(b p y)_{2}(d p m)\right]^{+}$derivatives have been described for their photophysical properties and potential applications in solar cells, their catalytic properties had not been explored. ${ }^{137,148-153}$ The resulting polymer was found to photocatalyze, under visible light, the reaction of tetrahydroisoquinoline with nitroalkanes such as nitromethane, as presented in Fig. 21, with a $98 \%$ conversion and the presence of a small amount of an oxidation product. Other nitroalkanes could be employed with high conversion rates but afford more of the undesired oxidation adduct. It is 
noteworthy that the reaction did not proceed in the absence of light and that the polymer retained its efficiency and selectivity through seven cycles, corresponding to more than 350 hours of irradiation.
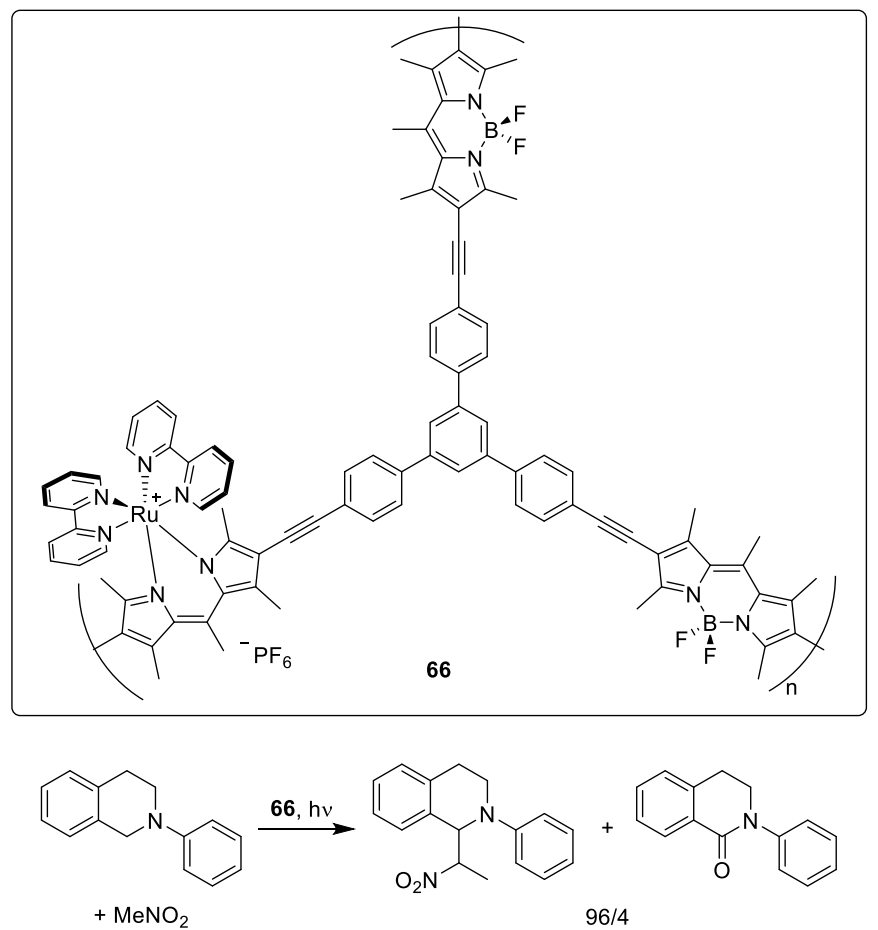

Fig. 21 Representation of a fragment of the BODIPY-based porous polymer $\mathbf{6 6}$ enriched with $\mathrm{Ru}(\mathrm{bpy})_{2}(\mathrm{dpm})$ units (top) and phototocatalyzed aza-Henry reaction as reported by Liras and coworkers. ${ }^{146}$ Only one enantiomer of the Ru complex is shown but both are present in the polymer.

Another approach for the development of heterogenous catalysts incorporating metal dpm complexes has been reported by the group of Pandey. ${ }^{154-155}$ Heteroleptic Ni(II) complexes comprising both a pyridine-appended dpm and a dithiocarbamate ligand were found to stabilize and functionalize Ag and Au nanoparticles. However, the role of the metal complexes in the investigated catalyses (reduction of 4-nitrophenol to 4-nitrophenolate for Ag nanoparticles and of $\mathrm{Cr}(\mathrm{VI})$ to $\mathrm{Cr}(\mathrm{III})$ for Au nanoparticles) has not been fully detailed. It clearly appears that they stabilize the metal aggregates but their actual mechanistic involvement in the catalyzed reaction has not been fully addressed.

\section{Conclusions}

Dipyrrin based metal complexes have been extensively investigated for a wide array of properties and applications such as in luminescent or porous materials, in supramolecular chemistry or in biology, for example. Interestingly, the study of the reactivity and catalytic activity of these compounds represents a more recent development. Sometimes coined half-porphyrins, dipyrrins analogously endow their complexes with unique properties such as the potential to functionalize the pyrrolic backbone or the meso position as well as the ability to favor interesting chemical transformations. Thus, while the derivatization of or at the meso group has been successfully explored, the $\alpha$-positions of the dpm chelate were also shown to be reactive. Indeed, not only alkoxylation is possible at this site, but the reactivity of these positions has also been taken advantage of for the formation of a broad range of polypyrrolic derivatives such as 2,2'-bis-dpms, nor-/hetero-corroles and porphynoids. The elaboration of these architectures relies on the use of template metal complexes. These compounds favor the close proximity of the pyrrolic rings and the metal cation exerts an electronic role facilitating the reaction. Beyond the modification of the bis-pyrrolic backbone, the dipyrrin-complexed metal cations play a role in a diversity of catalytic transformations. The chelating ability of dpm and the possibility to modify its 
steric and electronic characteristics by functionalization has been exploited for the development of numerous complexes featuring appealing activity. Hence, it has been demonstrated that $\mathrm{Fe}, \mathrm{Co}, \mathrm{Cu}$ and $\mathrm{Ni} \mathrm{dpm}$ complexes can be employed for $\mathrm{C}-\mathrm{H}$ activation/amination; a reactivity currently especially sought after. Furthermore, introduction of functional groups like phenolic moieties leads to noninnocent tetradentate species. The corresponding complexes have been demonstrated to catalyze efficiently polymerization or oxidation reactions. Finally, classical reagents such as Grignard species, Rh or Suzuki-Miyaura catalysts have been revisited by incorporation of dpm in the coordination sphere of the metal center, with convincing outcomes. In light of all these results, dipyrrin metal complexes appear as an interesting addition to the toolbox of catalysts required for the design and synthesis of valuable organic compounds. While additional reactivity under homogeneous conditions may be reported in the future, it seems that one promising area to be explored is the possibility to develop heterogeneous catalysts. For example, whereas $\mathrm{dpm}$ have been successfully used for the preparation of crystalline porous materials of the metal-organic frameworks type, the heterogenization of catalytically active dpm metal complexes into such crystalline architectures remains to be uncovered. This area and other potential endeavors suggest a great future for this research field.

\section{Conflicts of interest}

There are no conflicts to declare.

\section{Acknowledgements}

The contribution of Drs. Domingo Salazar-Mendoza, Dmitry Pogozhev, Catherine Bronner, Antoine Béziau, Hervé Ruffin, Fan Zhang, Antoine Mazel, and Damien Bechu as well as Nathan Trometer, Brandon Kilduff and Victor Koehler has been central to the research on dipyrrin metal complexes in our group. Financial support from CNRS, the Université de Strasbourg, the Ministère de l'Enseignement Supérieur, de la Recherche et de l'Innovation and the International Center for Frontier Research in Chemistry is gratefully acknowledged.

\section{References}

1 T. E. Wood and A. Thompson, Chem. Rev., 2007, 107, 1831-1861.

2 H. Fischer and M. Schubert, Ber. Dtsch. Chem. Ges., 1924, 57, 610-617.

3 N. Boens, V. Leen and W. Dehaen, Chem. Soc. Rev., 2012, 41, 1130-1172.

4 L. Wang, H. Ding, X. Ran, H. Tang and D. Cao, Dyes Pigments, 2020, 172, 107857.

5 A. Kamkaew, S. Hui Lim, H. Boon Lee, L. Voon Kiew, L. Yong Chun and K. Burgess, Chem. Soc. Rev., 2013, 42, 77-88.

6 B. Bertrand, K. Passador, C. Goze, F. Denat, E. Bodio, M. Salmain, Coord. Chem. Rev., 2018, 358, 108-124.

7 A. Bessette and G. S. Hanan, Chem. Soc. Rev., 2014, 43, 3342-3405.

8 S. A. Baudron, Dalton Trans., 2013, 42, 7498-7509.

9 S. A. Baudron, CrystEngComm., 2016, 18, 4671-4680.

10 S. A. Baudron, CrystEngComm., 2010, 12, 2288-2295.

11 R. Matsuoka and T. Nabeshima, Front. Chem., 2018, 6, 349.

12 R. Sakamoto, T. Iwashima, M. Tsuchiya, R. Toyoda, R. Matsuoka, J. F. Kögel, S. Kusaka, K. Hoshiko, T. Yagi, T. Nagayama and H. Nishihara, J. Mater. Chem. A, 2015, 3, 15357-15371.

13 T. L. Poulos, Chem. Rev., 2014, 114, 3919-3962.

14 W. Zhang, W. Lai and R. Cao, Chem. Rev., 2017, 117, 3717-3797.

15 J. C. Barona-Castaño, C. C. Carmona-Vargas, T. J. Brocksom and K. T. de Oliveira, Molecules, 2016, 21, 310.

16 X. Huang and J. T. Groves, Chem. Rev., 2018, 118, 2491-2553. 
17 S. Hiroto, Y. Miyake and H. Shinokubo, Chem. Rev., 2017, 117, 2910-3043.

18 J. F. B. Barata, M. G. P. M. S. Neves, M. A. F. Faustino, A. C. Tomé and J. A. S. Cavaleiro, Chem. Rev., 2017, 117, 3192-3253.

19 N. Boens, B. Verbelen, M. J. Ortiz, L. Jihao and W. Dehaen, Coord. Chem. Rev., 2019, 399, 213024.

20 C. Brückner, Y. Zhang, S. J. Rettig and D. Dolphin, Inorg. Chim. Acta, 1997, 263, 279-286.

21 S. J. Garibay, J. R. Stork, Z. Wang, S. M. Cohen and S. G. Telfer, Chem. Commun., 2007, 48814883.

22 C. Bronner, S. A. Baudron and M. W. Hosseini, Inorg. Chem., 2010, 49, 8659-8661.

23 S. G. Telfer and J. D. Wuest, Chem. Commun., 2007, 3166-3168.

24 S. G. Telfer and J. D. Wuest, Cryst. Growth Des., 2009, 9, 1923-1931

25 C. S. Gutsche, S. Gräfe, B. Gitter, K. J. Flanagan, M. O. Senge, N. Kulak and A. Wiehe, Dalton Trans., 2018, 47, 12373-12384.

26 L. Yu, K. Muthukumaran, I. V. Sazanovich, C. Kirmaier, E. Hindin, J. R. Diers, P. D. Boyle, D. F. Bocian, D. Holten and J. S. Lindsey, Inorg. Chem., 2003, 42, 6629-6647.

27 K. Muthukumaran, S. H. H. Zaidi, L. Yu, P. Thamyongkit, M. E. Calder, D. S. Sharada and J. S. Lindsey, J. Porphyrins Phthalocyanines, 2005, 9, 745-759.

28 D. Perl, S. W. Bisset and S. G. Telfer, Dalton Trans., 2016, 45, 2440-2443.

29 B. D. Gutiérez-Ramos, J. Baçuelos, T. Arbeloa, I. López Arbeloa, P. E. González-Navarro, K. Wrobel, L. Cerdán, I. García-Moreno, A. Costela and E. Peña-Cabrera, Chem. Eur. J., 2015, 21, 1755-1764.

30 T. M. McLean, J. L. Moody, M. R. Waterland and S. G. Telfer, Inorg. Chem., 2012, 51, 446-455. 31 S. R. Halper, J. R. Stork and S. M. Cohen, Dalton Trans., 2007, 1067-1074.

32 Z. Xiao, B. O. Patrick and D. Dolphin, Chem. Commun., 2003, 1062-1063.

33 R. K. Gupta, R. Pandey, S. Sharma and D. S. Pandey, Dalton Trans., 2012, 41, 8556-8566.

34 J. Kong, Q. Li, M. Li, X. Li, X. Liang, W. Zhu, H. Ågren and Y. Xie, Dyes Pigments, 2017, 137, 430436.

35 F. Zhang, A. Fluck, S. A. Baudron and M. W. Hosseini, Inorg. Chim. Acta, 2019, 494, 216-222.

36 A. Kämpfe, E. Kroke and J. Wagler, Organometallics, 2014, 33, 112-120.

37 C. O. Dietrich-Bucheker, J.-P. Sauvage and J.-P. Kintzinger, Tetrahedron Lett., 1983, 24, 50955098.

38 G. Gil-Ramírez, D. A. Leigh and A. J. Stephens, Angew. Chem. Int. Ed., 2015, 54, 6110-6150.

39 B. Nisanci, S. Sahinoglu, E. Tuner, M. Arik, I. Kani, A. Dastan and Ö. A. Bozdemir, Chem. Commun., 2017, 53, 12418-12421.

40 H. Maeda, T. Nishimura, R. Akuta, K. Takaishi, M. Uchiyama and A. Muranaka, Chem. Sci., 2013, 4, 1204-1211.

41 H. S. Gill, I. Finger, I. Božidarević, F. Szydlo and M. J. Scott, New J. Chem., 2005, 29, 68-71.

42 T. Hashimoto, T. Nishimura, J. M. Lin, D. Kim and H. Maeda, Chem. Eur. J., 2010, 16, 1165311661.

43 H. Ruffin, S. A. Baudron, D. Salazar-Mendoza and M. W. Hosseini, Chem. Eur. J., 2014, 20, 24492453.

44 S. A. Baudron, H. Ruffin and M. W. Hosseini, Chem. Commun., 2015, 51, 5906-5909.

45 F. Zhang, A. Fluck, S. A. Baudron and M. W. Hosseini, Dalton Trans., 2019, 48, 4105-4108.

$46 \mathrm{M}$. Bröring, Beyond dipyrrins: Coordination interaction and templated macrocyclizations of open-chain oligopyrroles, in K. M. Kadish, K. M. Smith, R. Guilard (Eds), Handbook of Porphyrin Science, World scientific, 2010, vol. 8, pp. 343-501.

47 R. Wicht, S. Bahnmüller, A. Thüsing, B. Wolfram and M. Bröring, Eur. J. Inorg. Chem., 2019, 4477-4485. 
48 T. Ito, Y. Hayashi, S. Shimizu, J.-Y. Shin, N. Kobayashi and H. Shinokubo, Angew. Chem. Int. Ed., 2012, 51, 8542-8545.

49 M. Bröring, S. Köhler and C. Kleeberg, Angew. Chem. Int. Ed., 2008, 47, 5658-5660.

50 S.-Y. Liu, H. Tanaka, R. Nozawa, N. Fukui and H. Shinokubo, Chem. Eur. J., 2019, 25, 7618-7622.

$51 \mathrm{~J}$. Conradie, C. Foroutan-Nejad and A. Ghosh, Sci. Rep., 2019, 9, 4852.

52 H. Kido, J.-Y. Shin and H. Shinokubo, Angew. Chem. Int. Ed., 2013, 52, 13727-13730.

53 R. L. N. Harris, A. W. Johnson and I. T. Kay, J. Chem. Soc. C, 1966, 22-29.

54 P. A. Stuzhin and O. G. Khelevina, Coord. Chem. Rev., 1996, 147, 41-86.

55 S. A. Shafie, H. Kawashima, Y. Miyake and H. Shinokubo, ChemPlusChem, 2019, 84, 623-626.

56 Y. Matano, T. Shibano, H. Nakano and H. Imahori, Chem. Eur. J., 2012, 18, 6208-6216.

57 Y. Matano, T. Shibano, H. Nakano, Y. Kimura and H. Imahori, Inorg. Chem., 2012, 51, 12879-

12890.

58 S. Omomo, Y. Tsuji, K. Sugiura, T. Higashino, H. Nakano, H. Imahori and Y. Matano, ChemPlusChem, 2017, 82, 695-704.

59 M. Horie, Y. Hayashi, S. Yamaguchi and H. Shinokubo, Chem. Eur. J., 2012, 18, 5919-5923.

60 T. Satoh, M. Minoura, H. Nakano, K. Furukawa and Y. Matano, Angew. Chem. Int. Ed., 2016, 55, 2235-2238.

61 K. Sudoh, T. Satoh, T. Amaya, K. Furukawa, M. Minoura, H. Nakano and Y. Matano, Chem. Eur. J., 2017, 23, 16364-13373.

62 M. Mutoh, K. Sudoh, K. Furukawa, M. Minoura, H. Nakano and Y. Matano, Asian J. Org. Chem., 2019, 8, 352-355.

63 K. Sudoh, T. Hatakeyama, K. Furukawa, H. Nakano and Y. Matano, J. Porphyrins Phthalocyanines, 2018, 22, 542-551.

64 K. Sudoh, K. Furukawa, H. Nakano, S. Shimizu and Y. Matano, Heteroatom Chem., 2018, 29, e21456.

65 H. Kamiya, T. Kondo, T. Sakida, S. Yamaguchi and H. Shinokubo, Chem. Eur. J., 2012, 18, 1612916135.

66 D. Sakow, B. Böker, K. Brandhorst, O. Burghaus and M. Bröring, Angew. Chem. Int. Ed., 2013, 52, 4912-4915.

67 H. Omori, S. Hiroto and H. Shinokubo, Chem. Eur. J., 2017, 23, 7866-7870.

68 Y. Matano, Chem. Rev., 2017, 117, 3138-3191.

69 E. R. King and T. A. Betley, Inorg. Chem., 2009, 48, 2361-2363.

70 A. B. Scharf and T. A. Betley, Inorg. Chem., 2011, 50, 6837-6845.

71 E. R. King, E. T. Hennessy and T. A. Betley, J. Am. Chem. Soc., 2011, 133, 4917-4923.

72 E. T. Hennessy, R. Y. Liu, D. A. lovan, R. A. Duncan and T. A. Betley, Chem. Sci., 2014, 5, 15261532.

73 E. T. Hennessy and T. A. Betley, Science, 2013, 340, 591-595.

74 J. Zheng, Z. Liu, X. Jin and Y. Dang, Catal. Sci. Technol., 2019, 9, 1279-1288.

75 D. A. Iovan, M. J. T. Wilding, Y. Baek, E. T. Hennessy and T. A. Betley, Angew. Chem. Int. Ed., 2017, 56, 15599-15602.

76 C. Kleinlein, S.-L. Zheng and T. A. Betley, Inorg. Chem., 2017, 56, 5892-5901.

77 D. A. lovan and T. A. Betley, J. Am. Chem. Soc., 2016, 138, 1983-1993.

78 M. J. T. Wilding, D. A. lovan and T. A. Betley, J. Am. Chem. Soc., 2017, 139, 12043-12049.

79 M. J. T. Wilding, D. A. lovan, A. T. Wrobel, J. T. Lukens, S. N. MacMillan, K. M. Lancaster and T.

A. Betley, J. Am. Chem. Soc., 2017, 139, 14757-14766.

80 C. Kleinlein, A. J. Bendelsmith, S.-L. Zheng and T. A. Betley, Angew. Chem. Int. Ed., 2017, 56, 12197-12201.

81 E. R. King, G. T. Sazama and T. A. Betley, J. Am. Chem. Soc., 2012, 134, 17858-17861. 
82 Y. Baek and T. A. Betley, J. Am. Chem. Soc., 2019, 141, 7797-7806.

83 Y. Baek, E. T. Hennessy and T. A. Betley, J. Am. Chem. Soc., 2019, 141, 16944-16953.

$84 \mathrm{~J}$. Cipot-Wechsler, A. Al-Sheikh Ali, E. E. Chapman, T. S. Cameron and A. Thompson, Inorg. Chem., 2007, 46, 10947-10949.

85 K. M. Carsch, I. M. DiMucci, D. A. Iovan, A. Li, S.-L. Zheng, C. J. Titus, S. J. Lee, K. D. Irvin, D. Nordlund, K. M. Lancaster and T. A. Betley, Science, 2019, 365, 1138-1143.

86 K. M. Carsch, J. T. Lukens, I. M. DiMucci, D. A. Iovan, A. Li, S.-L. Zheng, K. M. Lancaster and T. A. Betley, J. Am. Chem. Soc., 2020, 142, 2264-2276.

87 Y. Dong, J. T. Lukens, R. M. Clarke, S.-L. Zheng, K. M. Lancaster and T. A Betley, Chem. Sci., 2020, 11, 1260-1268.

88 D. A. lovan, A. T. Wrobel, A. A. McClelland, A. B. Scharf, G. A. Edouard and T. A. Betley, Chem. Commun., 2017, 53, 10306-10309.

89 E.J. Johnson, C. Kleinlein, R. A. Musgrave and T. A. Betley, Chem. Sci., 2019, 10, 6304-6310.

90 J. R. Pankhurst, T. Cadenbach, D. Betz, C. Finn and J. B. Love, Dalton Trans., 2015, 44, 20662070.

91 E. Katayev, K. Severin, R. Scopelliti and Y. A. Ustynyuk, Inorg. Chem., 2007, 46, 5465-5467.

92 J. R. Pankhurst, N. L. Bell, M. Zegke, L. N. Platts, C. Alvarez Lamfsus, P. L. Arnold and J. B. Love, Chem. Sci., 2017, 8, 108-116.

93 N. L. Bell, B. Shaw, P. L. Arnold, J. B. Love, J. Am. Chem. Soc., 2018, 140, 3378-3384.

94 D. Bolotaulo, A. Metta-Megaña and S. Fortier, Dalton Trans., 2017, 46, 3284-3294.

95 W. A. Reiter, A. Gerges, S. Lee, T. Deffo, T. Clifford, A. Danby and K. Bowman-James, Coord. Chem. Rev., 1998, 174, 343-359.

96 N. N. Gerasimchuk, A. Gerges, T. Clifford, A. Danby and K. Bowman-James, Inorg. Chem., 1999, 38, 5633-5636.

97 A. Ghosh, Chem. Rev., 2017, 117, 3798-3881.

98 S. M. Bloom and P.P. Garcia, Novel dipyrrylmethene dyes, US Patent 3691161, Sept. 121972.

99 H. Kim, A. Burghart, M. B. Welch, J. Reibenspies and K. Burgess, Chem. Commun., 1999, 18891890.

100 C. Ikeda, S. Ueda and T. Nabeshima, Chem. Commun., 2009, 2544-2546.

101 N. Sakamoto, C. Ikeda, M. Yamamura and T. Nabeshima, J. Am. Chem. Soc., 2011, 133, 4726-4729.

102 M. Yamamura, H. Takizawa, N. Sakamoto and T. Nabeshima, Tetrahedron Lett., 2013, 54, 7049-7052.

103 M. Yamamura, M. Albrecht, M. Albrecht, Y. Nishimura, T. Arai and T. Nabeshima, Inorg. Chem., 2014, 53, 1355-1360.

104 A. Sumiyoshi, Y. Chiba, R. Matsuoka, T. Noda and T. Nabeshima, Dalton Trans., 2019, 48, 13169-13175.

105 A. Kochem, L. Chiang, B. Baptiste, C. Philouze, N. Leconte, O. Jarjayes, T. Storr and F. Thomas, Chem. Eur. J., 2012, 18, 14590-14593.

106 Y. Feng, L. A. Burns, L.-C. Lee, C. D. Sherrill, C. W. Jones and C. Murdock, Inorg. Chim. Acta, 2015, 430, 30-35.

107 W. Shan, N. Desbois, S. Pacquelet, S. Brandès, Y. Rousselin, J. Conradie, A. Ghosh, C. P. Gros and K. M. Kadish, Inorg. Chem., 2019, 58, 7677-7689.

108 L. Lecarme, A. Kochem, L. Chiang, J. Moutet, F. Berthiol, C. Philouze, N. Leconte, T. Storr and F. Thomas, Inorg. Chem., 2018, 57, 9708-9719.

109 M. Yamamura, H. Takizawa, Y. Gobo and T. Nabeshima, Dalton Trans., 2016, 45, 68346838. 
110 K. E. Thomas, N. Desbois, J. Conradie, S. J. Teat, C. P. Gros and A. Ghosh, RSC Adv., 2020, 10, 533-540.

111 J. T. Groves and S. S. Marla, J. Am. Chem. Soc., 1995, 117, 9578-9579.

112 A. Mahammed and Z. Gross, Angew. Chem. Int. Ed., 2006, 45, 6544-6547.

113 S. Rausaria, A. Kamadulski, N. P. Rath, L. Bryant, Z. Chen, D. Salvemini and W. L. Neumann, J. Am. Chem. Soc., 2011, 133, 4200-4203.

114 S. El Ghachtouli, K. Wójcik, L. Copey, F. Szydlo, E. Framery, C. Goux-Henry, L. Billon, M.-F. Charlot, R. Guillot, B. Andrioletti and A. Aukauloo, Dalton Trans., 2011, 40, 9090-9093.

115 L. Lecarme, L. Chiang, J. Moutet, N. Leconte, C. Philouze, O. Jarjayes, T. Storr and F. Thomas, Dalton Trans., 2016, 45, 16325-16334.

116 K. Nakano, K. Kobayashi and K. Nozaki, J. Am. Chem. Soc., 2011, 133, 10720-10723.

117 T. Ohkawara, K. Suzuki, K. Nakano, S. Mori and K. Nozaki, J. Am. Chem. Soc., 2014, 136, 10728-10735.

118 M. H. Chisholm, K. Choojun, J. C. Gallucci and P. M. Wambua, Chem. Sci., 2012, 3, 34453457.

119 G. Ballmann, H. Elsen, S. Harder, Angew. Chem. Int. Ed., 2019, 58, 15736-15741.

120 C. Kumar Jha, S. Karwasara and S. Nagendran, Chem. Eur. J., 2014, 20, 10240-10244.

121 C. G. Gionopoulos, K. Kirschbaum and M. R. Mason, Organometallics, 2014, 33, 4503-4511.

122 C. G. Gionopoulos, N. Kumar, Y. Zhao, L. Jia, K. Kirschbaum and M. R. Mason, Dalton Trans., 2016, 45, 13787-13797.

123 K. Fagnou and M. Lautens, Chem. Rev., 2003, 103, 169-196.

124 D. A. Colby, R. G. Bergman and J. A. Ellman, Chem. Rev., 2010, 110, 624-655.

125 N. W. Roomi, Tetrahedron Lett., 1974, 13, 1131-1132.

126 R. H. Lam, D. B. Walker, M. H. Tucker, M. R. D. Gatus, M. Bhadbhade and B. A. Messerle, Organometallics, 2015, 34, 4312-4317.

127 Z. Liu, J. Guo, C. Song, W. Hu, Y. Dang and Z.-X. Wang, Eur. J. Inorg. Chem., 2017, 27132722.

128 E. A. Leushina, D. N. Gorbunov, D. A. Cheshkov, T. S. Kuchinskaya, A. V. Anisimov, A. L. Maksimov, M. V. Terenina, A. V. Khoroshutin and E. A. Karakhanov, Russ. J. Org. Chem., 2016, 52, 1625-1631.

129 M. Yadav, A. K. Singh, B. Maiti and D. S. Pandey, Inorg. Chem., 2009, 48, 7593-7603.

130 M. Yadav, A. K. Singh and D. S. Pandey, Organometallics, 2009, 28, 4713-4723.

131 M. Yadav, A. K. Singh, R. Pandey and D. S. Pandey, J. Organomet. Chem., 2010, 695, 841849.

132 M. Yadav, P. Kumar and D. S. Pandey, Polyhedron, 2010, 29, 791-800.

133 R. K. Gupta, R. Pandey, G. Sharma, R. Prasad, B. Koch, S. Srikrishna, P.-Z. Li, Q. Xu and D. S. Pandey, Inorg. Chem., 2013, 52, 3687-3698.

134 R. K. Gupta, G. Sharma, R. Pandey, A. Kumar, B. Koch, P.-Z. Li, Q. Xu and D. S. Pandey, Inorg. Chem., 2013, 52, 13984-13996.

135 N. Miyaura and A. Suzuki, Chem. Rev., 1995, 95, 2457-2483.

136 C. Bronner, S. A. Baudron, M. W. Hosseini, C. A. Strassert, A. Guenet and L. De Cola, Dalton Trans., 2010, 39, 180-184.

137 J. D. Hall, T. M. McLean, S. J. Smalley, M. R. Waterland and S. G. Telfer, Dalton Trans., 2010, 39, 437-445.

138 R. K. Gupta, R. Pandey, R. Singh, N. Srivastava, B. Maiti, S. Saha, P. Li, Q. Xu and D. S. Pandey, Inorg. Chem., 2012, 51, 8916-8930.

139 V. Kumar, V. Singh, A. N. Gupta, S. K. Singh, M. G. B. Drew and N Singh, Polyhedron, 2015, 89,304-312. 
140 P. Isar, T. Chatterjee and M. Ravikanth, ChemistrySelect, 2016, 6, 1220-1224.

141 A. Kumar, S. Kumar, T. Chatterjee and M. Ravikanth, ChemistrySelect, 2016, 1, 94-99.

142 S. Riese, M. Holzapfel, A. Schmiedel, I. Gert, D. Schmidt, F. Würthner and C. Lambert, Inorg. Chem., 2018, 57, 12480-12488.

143 R. M. Diaz-Rodriguez, K. N. Robertson and A. Thompson, Dalton Trans., 2019, 48, 75467550.

144 G. Su, Q. Li, M. Ishida, C. Li, F. Sha, X.-Y. Wu, L.Wang, G. Baryshnikov, D. Li, H. Ågren, H. Furuta and Y. Xie, Angew. Chem. Int. Ed., 2020, 59, 1537-1541.

145 C. J. Curtis and E. Tomat, J. Porphyrins Phthalocyanines, 2020, 24, 112-120.

146 M. Liras, M. Pintado-Sierra, M. Iglesias and F. Sanchez, J. Mater. Chem. A, 2016, 4, 1727417278.

147 M. Liras, M. Iglesias and F. Sánchez, Macromolecules, 2016, 49, 1666-1673.

148 S. J. Smalley, M. R. Waterland and S. G. Telfer, Inorg. Chem., 2009, 48, 13-15.

149 G. Li, P. G. Bomben, K. C. D. Robson, S. I. Gorelsky, C. P. Berlinguette and M. Shatruk, Chem. Commun., 2012, 48, 879-8792.

150 G. Li, L. Ray, E. N. Glass, K. Kovnir, A. Khoroshutin, S. I. Gorelsky and M. Shatruk, Inorg. Chem., 2012, 51, 1614-1624.

151 G. Li, K. Hu, C. Yi, K. L. Knappenberger, Jr., G. J. Meyer, S. I. Gorelsky and M. Shatruk, J. Phys. Chem. C, 2013, 117, 17399-17411.

152 G. Li, K. Hu, K. C. D. Robson, S. I. Gorelsky, G. J. Meyer, C. P. Berlinguette and M. Shatruk, Chem. Eur. J., 2015, 21, 2173-2181.

153 B. F. Hohlfeld, K. J. Flanagan, N. Kulak, M. O. Senge, M. Christmann and A. Wiehe, Eur. J. Org. Chem., 2019, 4020-4033.

154 R. K. Gupta, M. Dubey, P. Z. Li, Q. Xu and D. S. Pandey, Inorg. Chem., 2015, 54, 2500-2511.

155 R. K. Gupta, V. Kumar, A. Srivastava, D. S. Pandey, RSC Adv., 2016, 6, 40911-40915.
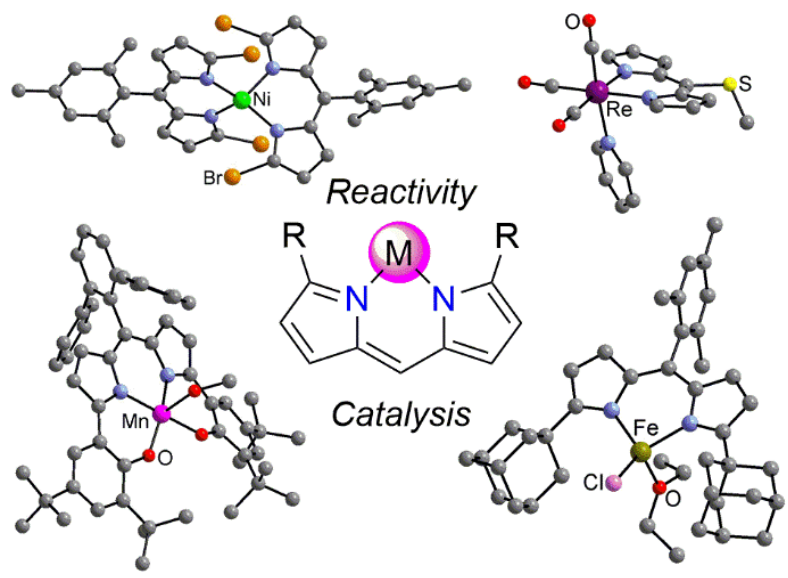

Table of contents This Perspective reviews the use of dipyrrin based metal complexes as catalysts and as templates towards polypyrrolic architectures. 